\title{
Examination of alkali-activated material nanostructure during thermal treatment
}

\author{
Brant Walkley ${ }^{1, \star}$ (D) Alireza Kashani ${ }^{2}$, Marc-Antoine Sani $^{3}$, Tuan D. $\mathrm{Ngo}^{2}$, and Priyan Mendis ${ }^{2}$ \\ ${ }^{1}$ Department of Materials Science and Engineering, The University of Sheffield, Sheffield S1 3JD, UK \\ ${ }^{2}$ Department of Infrastructure Engineering, The University of Melbourne, Parkville, VIC 3010, Australia \\ ${ }^{3}$ School of Chemistry and Bio21 Institute, The University of Melbourne, Parkville, VIC 3010, Australia
}

Received: 4 December 2017

Accepted: 26 March 2018

Published online:

5 April 2018

(C) The Author(s) 2018

\begin{abstract}
The key nanostructural changes occurring in a series of alkali-activated materials (AAM) based on blends of slag and fly ash precursors during exposure to temperatures up to $1000{ }^{\circ} \mathrm{C}$ are investigated. The main reaction product in each AAM is a crosslinked sodium- and aluminium-substituted calcium silicate hydrate (C-(N)-A-S-H)-type gel. Increased alkali content promotes the formation of an additional sodium aluminosilicate hydrate (N-A-S-(H)) gel reaction product due to the structural limitations on $\mathrm{Al}$ substitution within the C-(N)-A-S-H gel. Heating each AAM to $1000{ }^{\circ} \mathrm{C}$ results in the crystallisation of the disordered gels and formation of sodalite, nepheline and wollastonite. Increased formation of N-A-S- $(\mathrm{H})$ reduces binder structural water content after thermal treatment and correlates closely with previous observations of improved strength retention and reduced microcracking in these AAM after heating to $1000{ }^{\circ} \mathrm{C}$. This provides new insight into thermally induced changes to gel atomic structure and thermal durability of C-(N)-A-S-H/N-A-S-H gel blends which are fundamental for the development of new fire-resistant construction materials.
\end{abstract}

\section{Introduction}

Alkali-activated materials (AAM) have shown extensive promise as sustainable alternatives to Portland cement (PC), exhibiting desirable technical and environmental characteristics for a large array of applications [1]. AAM have received particular attention from academia and industry due to observations of excellent thermal performance, retaining strength after exposure to the temperatures in excess of $1000{ }^{\circ} \mathrm{C}$ which commonly result from structural fires [2-7].
This contrasts with PC which is susceptible to severe loss of strength and/or spalling at high temperatures $[8,9]$, particularly for low-porosity, high-performance concretes. The superior thermal performance of AAM is generally attributed to the differences in the structure of these materials when compared to that of hydrated PC, which rapidly loses strength when exposed to temperatures above $300{ }^{\circ} \mathrm{C}$ due to loss of structural water from hydrate phases [7].

The main binding phase in an alkali-activated cement based on blast furnace slag is a calcium

Address correspondence to E-mail: b.walkley@sheffield.ac.uk 
(alkali) aluminosilicate hydrate (C-(N)-A-S-H) gel with structural similarity to substituted tobermoritegroup minerals, displaying crystallinity ranging from X-ray amorphous to poorly crystalline [10-12]. In contrast, the main binding phase in an alkali-activated cement based on fly ash is an alkali aluminosilicate hydrate (N-A-S-(H)) gel framework with a highly polymerised, disordered pseudo-zeolitic structure containing low amounts of structural water [1]. The N-A-S-(H) gel is X-ray amorphous but has been shown to exhibit short-range ordering and to be comprised of nanocrystalline zeolites compacted by an amorphous gel phase [13].

Blended slag/fly ash-based AAM can exhibit advantages, in terms of the balance between reaction kinetics and durability, over those produced from sole precursors [14-16], but the coexistence of C-(N)A-S-H and N-A-S-(H) gels results in complex thermodynamic and chemical interactions which dictate material properties and performance $[17,18]$. Coexistence of these gels has been observed in alkali-activated cement based on blast furnace slag [11, 19] and blends of low-Ca and high-Ca precursors $[18,20-22]$. The stability of this coexistence remains to some degree unclear [23-25], with the C-(N)-A-S-H gel framework observed to be the dominant gel in synthetic C-(N)-A-S-H/N-A-S-(H) gel blends [25].

The gel nanostructure of AAM plays an important role in thermal resistance. High-performance concrete based predominantly on hydrated PC exhibits dense binder structures and tortuous pore networks, and consequently experience explosive spalling at high temperatures due to the generation of high internal water vapour pressure [26, 27]. The pore network structure within AAM is dictated by gel nanostructure and has been shown to control internal water vapour pressure at elevated temperatures, with increased porosity and decreased tortuosity in the pore network providing improved resistance to fire spalling due to easier release of trapped water vapour and reduction in internal water vapour pressure $[4-7,28]$. Increased alkali and $\mathrm{Al}$ content has been shown to improve strength retention and reduce microcracking in AAM exposed to temperatures in excess of $1000{ }^{\circ} \mathrm{C}$ [6]. Additional observations have suggested that the gel Si/Al ratio [5, 28-30] and particle size distribution [7] of the precursor material influence thermal performance of AAM systems; however, this influence is likely to be indirect as both of these parameters influence the degree of reaction, structural water content of the gel $[17,31]$ and pore network structure [32] of the binder.

Despite the extensive focus on the mechanical properties and microstructure of AAM exposed to high temperatures and demanding thermal environments (i.e. those with rapid changes in temperature), little attempt has been made to examine thermally induced changes to gel nanostructure and chemistry. These changes are of particular importance as they ultimately dictate the structural water content, pore network structure and consequently the thermal performance of these materials. Understanding nanoand atomic-scale phase and structural evolution during exposure to elevated temperatures is crucial for formulation and design of AAM optimised for high durability, strength and thermal performance. Here we investigate the composition-structureproperty relationships in a series of AAM based on blends of slag and fly ash precursors by identifying the key nanostructural changes occurring during exposure to temperatures up to $1000{ }^{\circ} \mathrm{C}$. This provides new insight into thermally induced changes to gel atomic structure and thermal durability of C-(N)A-S-H/N-A-S-H gel blends.

\section{Experimental procedures}

\section{Alkali-activated cement synthesis}

Ground granulated blast furnace slag (GGBFS) and fly ash were purchased from Cement Australia; the chemical composition as determined by X-ray fluorescence (XRF) analysis is shown in Table 1. A commercial blend ('Melbourne Ash') of moderatecalcium fly ashes based on fly ashes from Gladstone and Callide power stations, Australia, was used.

Solid precursors were produced by blending the fly ash and slag precursors in a 4:1 ratio. Activating solutions were prepared by dissolution of solid sodium hydroxide (99.9\% purity, analytical grade, Chem-Supply, Australia) in water followed by addition of sodium silicate solution (molar ratio $\mathrm{SiO}_{2}$ / $\mathrm{Na}_{2} \mathrm{O}=2$, Grade D, PQ Australia). Six AAM samples (each with a different composition) were made by mixing the activating solutions with the solid precursors.

Compositions were chosen to exhibit chemistry within the quaternary $\mathrm{CaO}-\mathrm{Na}_{2} \mathrm{O}-\mathrm{Al}_{2} \mathrm{O}_{3}-\mathrm{SiO}_{2}$ system which are important for studying N-A-S-(H)/C-(N)- 
Table 1 Precursor chemical composition (wt\%) as determined by XRF

\begin{tabular}{lllllllllllll}
\hline & $\mathrm{Na}_{2} \mathrm{O}$ & $\mathrm{MgO}$ & $\mathrm{Al}_{2} \mathrm{O}_{3}$ & $\mathrm{SiO}_{2}$ & $\mathrm{P}_{2} \mathrm{O}_{5}$ & $\mathrm{SO}_{3}$ & $\mathrm{~K}_{2} \mathrm{O}$ & $\mathrm{CaO}$ & $\mathrm{TiO}_{2}$ & $\mathrm{MnO}$ & $\mathrm{Fe}_{2} \mathrm{O}_{3}$ & Total \\
\hline Fly Ash & 0.81 & 1.27 & 25.13 & 42.09 & 1.10 & 0.41 & 0.41 & 13.56 & 1.44 & 0.18 & 13.16 & 100 \\
Slag & 1.51 & 5.56 & 14.01 & 32.83 & 0.07 & 2.28 & 0.35 & 41.90 & 0.53 & 0.22 & 0.50 & 100 \\
\hline
\end{tabular}

A-S-H-type gel blends [17, 18]. Previous work has shown that the alkali content $(\mathrm{Na} / \mathrm{Si}$ ratio) of the reaction mixture dictates the amount of each gel formed in N-A-S-(H)/C-(N)-A-S-H-type gel blends [33-37]. Alkali content was therefore varied in the samples used in the work presented here to examine how this affects thermally induced nanostructural changes. Nominal reaction mix compositions are shown in Fig. 1 and Table $2(\mathrm{w} / \mathrm{s}=0.35$ for all samples). All samples were mixed with a Hobart mixer for $10 \mathrm{~min}$ and subsequently cast into moulds. Samples were then vibrated for 5 min using a vibrating table to compact the paste and release any entrained air and subsequently sealed and cured at ambient temperature $\left(\sim 23^{\circ} \mathrm{C}\right)$ for 14 days. This period was chosen to examine the thermally induced nanostructural changes of these samples during the early stages of curing.

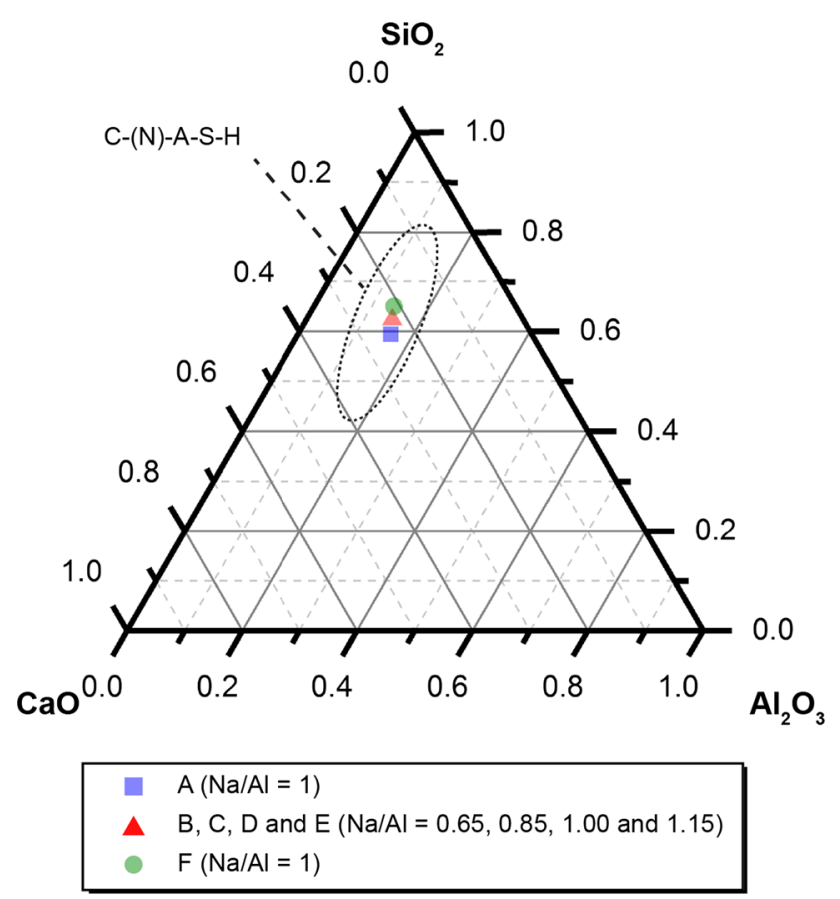

Figure 1 Projection of nominal alkali-activated material chemistry onto the ternary $\mathrm{CaO}-\mathrm{Al}_{2} \mathrm{O}_{3}-\mathrm{SiO}_{2}$ system (neglecting $\mathrm{Na}_{2} \mathrm{O}$ content) for samples $\mathrm{A}-\mathrm{F}$ as marked. $\mathrm{Na} / \mathrm{Al}$ ratios for each sample are indicated, and $\mathrm{w} / \mathrm{s}=0.35$ for all samples. Approximate region for C-(N)-A-S-H determined from [38].
Samples to be thermally treated were heated to $1000{ }^{\circ} \mathrm{C}$ in an electric furnace at a rate of $6.6^{\circ} \mathrm{C} / \mathrm{min}$, held at $1000{ }^{\circ} \mathrm{C}$ for $1 \mathrm{~h}$ and then cooled to room temperature at a rate of $6.6^{\circ} \mathrm{C} / \mathrm{min}$. This temperature was chosen to simulate air temperatures which occur in residential and commercial building fire scenarios (based on Australian Standard AS 1530.4 and American Standard ASTM E119) [2]. Six 50-mm cubic samples which had been cured for 14 days were placed in the furnace with only the bottom surface contacted, with heat exposure to the other surfaces via air convection. A detailed microstructural and mechanical analysis of these samples has been discussed previously [6].

\section{Characterisation}

With the exception of scanning electron microscopy, the hardened binders were hand ground using a pestle and mortar, immersed in acetone for $15 \mathrm{~min}$ to remove loosely bound water (thereby halting the alkali-activation reaction without significantly altering the AAM gel structure [39]), and subsequently filtered prior to storing in a sealed desiccator.

A Spectro 'Xepos' energy-dispersive x-ray fluorescence (XRF) spectrometer was used to obtain chemical composition data of the precursors. Samples fused with a 12:22 lithium tetraborate:metaborate flux in platinum crucibles at $1050{ }^{\circ} \mathrm{C}$ for $15 \mathrm{~min}$ prior to analysis.

X-ray diffraction (XRD) data were obtained across a $2 \theta$ range of $5^{\circ}-70^{\circ}$ using a Bruker D8 Advance instrument with $\mathrm{Cu} \mathrm{K} \alpha$ radiation (1.54 $\AA$ ), a nickel filter, a step size of $0.020^{\circ}, 1 \mathrm{~s} / \mathrm{step}$ and rotating at $15 \mathrm{rpm}$. Diffracted background intensity at low angles was reduced using an anti-scatter blade, and an incident beam divergence of $1.0 \mathrm{~mm}$ and a $2.5^{\circ}$ Soller slit in the diffracted beam were used. Phase identification was performed using Diffrac.EVA V4.1 software with the ICDD PDF4+ 2015 database.

Scanning electron microscopy (SEM) was performed using a Hitachi TM 3030 instrument with a $15 \mathrm{kV}$ accelerating voltage, a working distance of $8 \mathrm{~mm}$ and a backscatter detector. An evenly 
Table 2 Reaction mixture mass fraction and molar ratios for each AAM sample

\begin{tabular}{|c|c|c|c|c|c|c|c|}
\hline & & A & $\mathrm{B}$ & $\mathrm{C}$ & $\mathrm{D}$ & E & $\mathrm{F}$ \\
\hline \multirow[t]{11}{*}{ Mass $\%$} & $\mathrm{Na}_{2} \mathrm{O}$ & 11.39 & 7.29 & 9.32 & 10.79 & 12.21 & 10.25 \\
\hline & $\mathrm{MgO}$ & 1.74 & 1.71 & 1.68 & 1.65 & 1.62 & 1.57 \\
\hline & $\mathrm{Al}_{2} \mathrm{O}_{3}$ & 18.73 & 18.45 & 18.04 & 17.75 & 17.47 & 16.87 \\
\hline & $\mathrm{SiO}_{2}$ & 40.85 & 45.67 & 44.66 & 43.94 & 43.24 & 46.73 \\
\hline & $\mathrm{P}_{2} \mathrm{O}_{5}$ & 0.73 & 0.72 & 0.70 & 0.69 & 0.68 & 0.66 \\
\hline & $\mathrm{SO}_{3}$ & 0.64 & 0.63 & 0.62 & 0.61 & 0.60 & 0.58 \\
\hline & $\mathrm{K}_{2} \mathrm{O}$ & 0.33 & 0.32 & 0.31 & 0.31 & 0.30 & 0.29 \\
\hline & $\mathrm{CaO}$ & 15.72 & 15.49 & 15.15 & 14.90 & 14.66 & 14.16 \\
\hline & $\mathrm{TiO}_{2}$ & 1.03 & 1.01 & 0.99 & 0.97 & 0.96 & 0.93 \\
\hline & $\mathrm{MnO}$ & 0.15 & 0.15 & 0.15 & 0.15 & 0.14 & 0.14 \\
\hline & $\mathrm{Fe}_{2} \mathrm{O}_{3}$ & 8.69 & 8.56 & 8.37 & 8.24 & 8.11 & 7.83 \\
\hline \multirow[t]{4}{*}{ Molar ratio } & $\mathrm{Si} / \mathrm{Al}$ & 1.85 & 2.1 & 2.1 & 2.1 & 2.1 & 2.35 \\
\hline & $\mathrm{Na} / \mathrm{Al}$ & 1 & 0.65 & 0.85 & 1 & 1.15 & 1 \\
\hline & $\mathrm{Ca} / \mathrm{Si}$ & 0.41 & 0.36 & 0.36 & 0.36 & 0.36 & 0.41 \\
\hline & $\mathrm{Ca} /(\mathrm{Al}+\mathrm{Si})$ & 0.27 & 0.25 & 0.25 & 0.25 & 0.25 & 0.27 \\
\hline
\end{tabular}

distributed selection of points across a representative $400 \mu \mathrm{m} \times 400 \mu \mathrm{m}$ section of the sample was analysed using a Bruker Quantax 70 X-ray energy-dispersive spectroscopy (EDX) detector to determine chemical compositions.

An Agilent VNMRS-600 spectrometer $\left(\mathrm{B}_{0}=14.1 \mathrm{~T}\right)$ and a $4.0-\mathrm{mm}$ triple resonance bioMAS probe were used to obtain solid-state ${ }^{29} \mathrm{Si},{ }^{27} \mathrm{Al}$, and ${ }^{23} \mathrm{Na}$ MAS NMR spectra (see Table 3 for experimental parameters). All data were processed using NMRPipe [40]. Gaussian peak profiles were used to deconvolute the ${ }^{29} \mathrm{Si}$ MAS NMR spectra [41]. The minimum number of peaks possible were fitted, and peak full width at half height was restricted to $\leq 5 \mathrm{ppm}$ for C-(N)-A-S-H gel products and $\leq 6 \mathrm{ppm}$ for N-A-S-(H) gel products. Peak intensities were required to be consistent with the structural constraints described by the 'Crosslinked Substituted Tobermorite Model' (CSTM) for C-(N)-A-S-H gel products [11], and the thermodynamics of a statistical distribution of $\mathrm{Si}$ and $\mathrm{Al}$ sites within a $\mathrm{Q}^{4}$ aluminosilicate network for N-A-S(H) gel products [42]. Previous work utilising ${ }^{29} \mathrm{Si}$ and ${ }^{27} \mathrm{Al}$ MAS NMR and Fourier transform infrared spectroscopy has shown that these models best describe the environments in which $\mathrm{Si}$ and $\mathrm{Al}$ exist in C-(N)-A-S-H [10-12, 17] and N-A-S-(H) [31, 42-45] gels.

The contribution from unreacted precursor particles was accounted for by fitting a scaled component spectrum calculated from the spectra of the slag and fly ash precursors. The minimum number of peaks necessary were fitted to account for the intensity within the region where $\mathrm{C}-(\mathrm{N})-\mathrm{A}-\mathrm{S}-\mathrm{H}$ Si sites are expected to resonate, subject to the structural constraints described by the CSTM [11]. The minimum number of peaks necessary were then fitted to account for the remaining intensity within the region where N-A-S- $(\mathrm{H}) \mathrm{Si}$ sites are expected to resonate, subject to the structural constraints described the thermodynamics of a statistical distribution of $\mathrm{Si}$ and

Table 3 Single pulse MAS NMR experiment parameters

\begin{tabular}{|c|c|c|c|c|c|c|c|}
\hline Nucleus & $\begin{array}{l}\text { Field } \\
\text { strength }(\mathrm{T})\end{array}$ & $\begin{array}{l}\text { Transmitter frequency } \\
(\mathrm{MHz})\end{array}$ & $\begin{array}{l}\text { Pulse width }(\mu s) \text { and } \\
\text { angle }\end{array}$ & $\begin{array}{l}\text { Relaxation } \\
\text { delay (s) }\end{array}$ & Scans & $\begin{array}{l}\text { Spinning speed } \\
(\mathrm{kHz})\end{array}$ & $\begin{array}{l}\text { Reference } \\
\left(\delta_{\text {iso }} / \mathrm{ppm}\right)\end{array}$ \\
\hline${ }^{29} \mathrm{Si}$ & 14.1 & 119.14 & $7.0(\pi / 2)$ & 60 & 1024 & 10.0 & $\begin{array}{l}\mathrm{Si}\left(\mathrm{CH}_{3}\right)_{4}(\mathrm{aq}) \\
(0.0 \mathrm{ppm})\end{array}$ \\
\hline${ }^{27} \mathrm{Al}$ & 14.1 & 156.27 & $4.0(\pi / 6)$ & 1.5 & 1024 & 8.0 & $\begin{array}{l}\mathrm{AlCl}_{3} \cdot 6 \mathrm{H}_{2} \mathrm{O} \\
(0.0 \mathrm{ppm})\end{array}$ \\
\hline${ }^{23} \mathrm{Na}$ & 14.1 & 158.64 & $5.0(\pi / 6)$ & 3 & 512 & 10.0 & $\begin{array}{l}\mathrm{NaCl}_{(\mathrm{s})} \\
(7.2 \mathrm{ppm})[46]\end{array}$ \\
\hline
\end{tabular}


$\mathrm{Al}$ sites within a $\mathrm{Q}^{4}$ aluminosilicate network for N-A$\mathrm{S}-(\mathrm{H})$ gel products [42].

\section{Results and discussion}

\section{X-ray diffraction}

X-ray diffraction data for the precursors, as-cured AAM and thermally treated (to $1000{ }^{\circ} \mathrm{C}$ ) AAM are shown in Figs. 2, 3, and 4, respectively. Both the slag and fly ash precursors exhibit a dominant broad feature characteristic of their amorphous content. Crystalline phases identified in the fly ash are quartz (PDF \# 00-001-0649), mullite (PDF \# 00-015-0776), hematite (PDF \# 00-033-0664), magnetite (PDF \# 04-007-1060) and gypsum (PDF \# 00-033-0311), while the slag also contains gypsum as a grinding aid, as well as an identifiable quantity of tricalcium silicate (identified as hatrurite, PDF \# 04-011-1393) and tricalcium aluminate (PDF \# 01-074-7039), likely to have been introduced as Portland cement contamination

\begin{tabular}{|ccr|}
\hline$Q$ - quartz & He-Hematite & $\underline{M}$ - Magnetite \\
M-mullite & G-gypsum & $\underline{\mathrm{C} \text {-tricalcium silicate }}$ \\
\hline
\end{tabular}
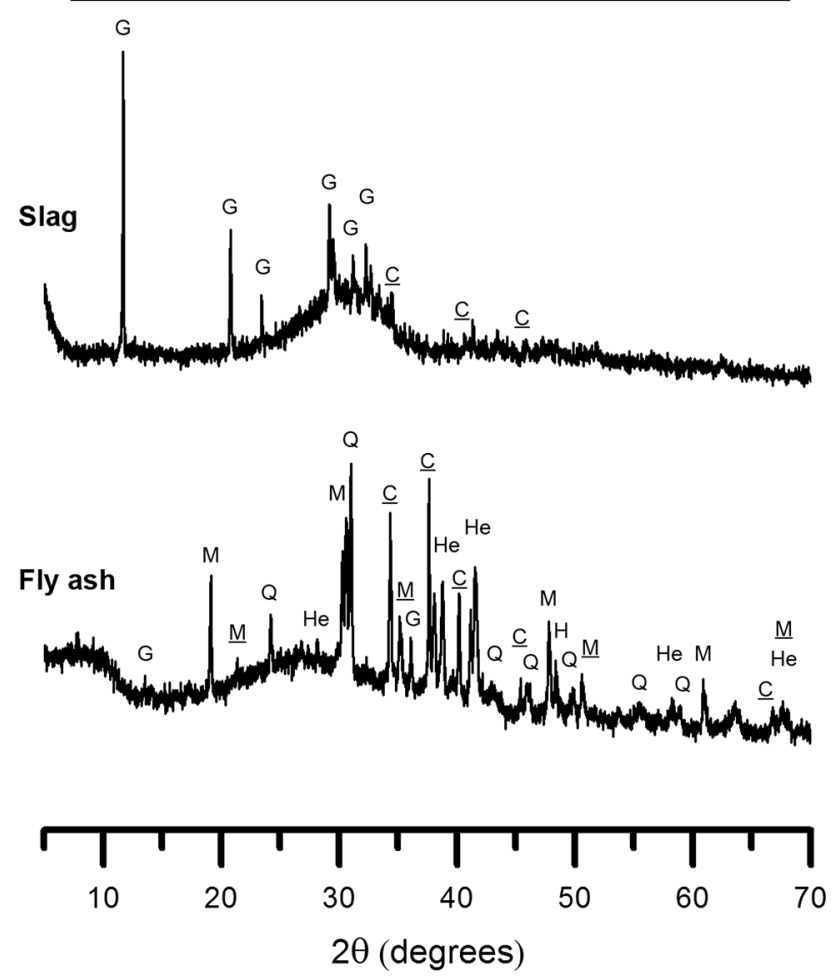

Figure 2 X-ray diffractograms of the blast furnace slag and fly ash precursors.
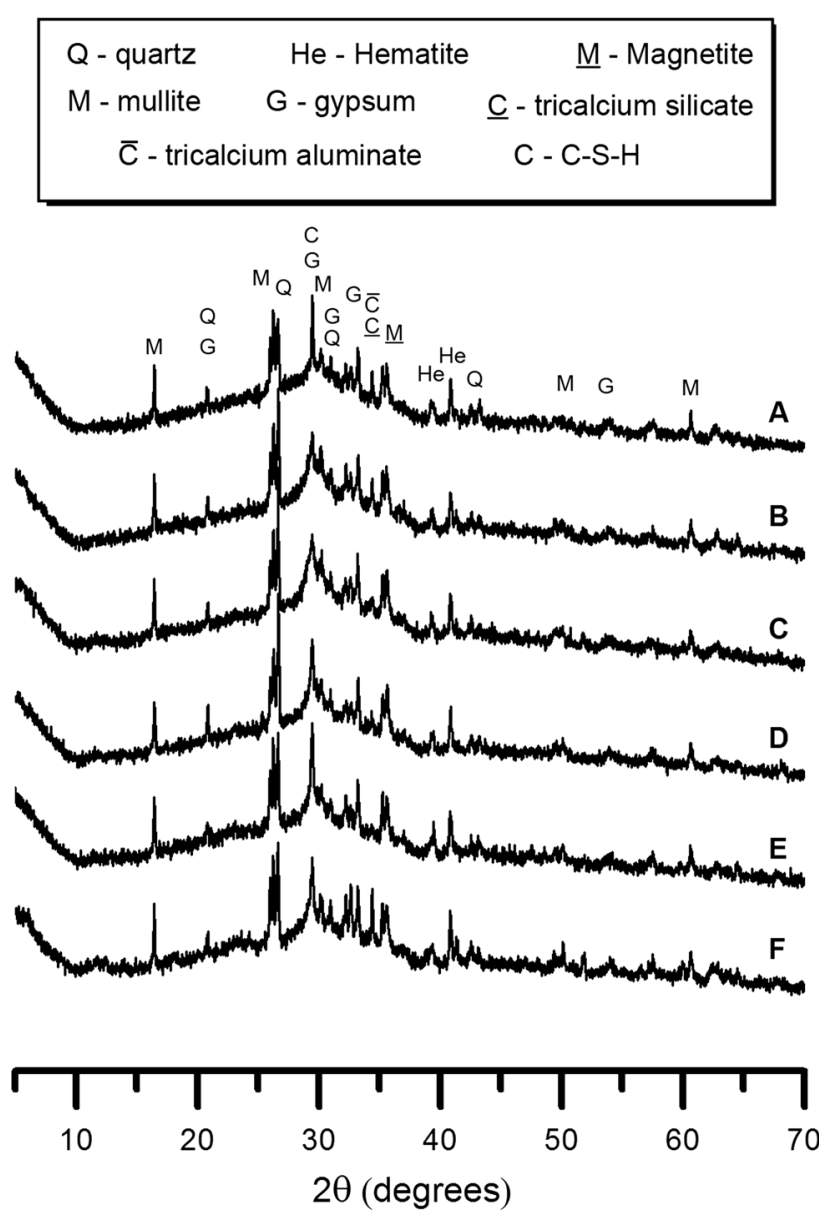

Figure 3 X-ray diffractograms of each AAM sample cured for 14 days.

during blending, grinding and/or transport of the fly ash and slag. The other usual Portland cement clinker constituent dicalcium silicate is not observed but is likely to be present below the detection limit of the technique used here.

The appearance of a broad feature upon alkali activation of all samples indicates the formation of an amorphous reaction product and the position of this feature at approximately $29^{\circ} 2 \theta$ is consistent with formation of an amorphous N-A-S-(H) phase (Fig. 3). A broad peak at approximately $29^{\circ} 2 \theta$ (overlapping significantly with the broad feature due to N-A-S$(\mathrm{H})$ ) indicates a phase with structural similarity to aluminium-containing tobermorite (PDF \# 00-0190052) and is assigned to a poorly crystalline C-(A)-S$\mathrm{H}$ phase [17]. Reflections due to all crystalline phases identified in the precursors are also present in the diffractogram for each AAM (Fig. 3); quartz, mullite, and iron oxides are unreactive during alkali activation on the timescale investigated here [18, 47]. 


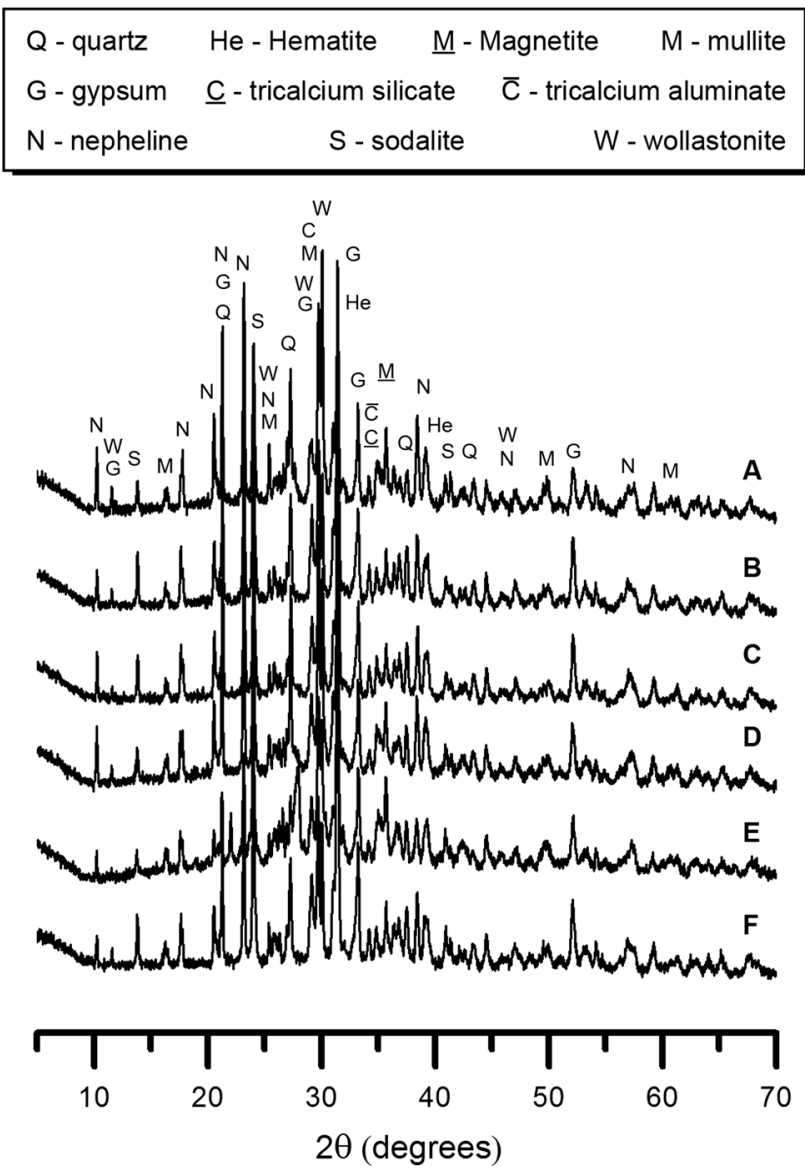

Figure 4 X-ray diffractograms of each AAM sample cured for 14 days and heated to $1000{ }^{\circ} \mathrm{C}$.

After thermal treatment, the diffractograms of each AAM show no evidence of the broad feature that was centred at approximately $29^{\circ} 2 \theta$ in the unheated materials, and high-intensity reflections attributed to crystalline phases present in the precursors are observed, suggesting devitrification of unreacted fly ash particles and partial crystallisation of disordered gel reaction products [48]. Reflections attributed to sodalite $\left(\mathrm{Na}_{8}\left[\mathrm{Al}_{6} \mathrm{Si}_{6} \mathrm{O}_{24}\right] \mathrm{Cl}_{2}\right.$, PDF \# 01-087-0296) and nepheline $\left(\mathrm{NaAl}\left(\mathrm{SiO}_{4}\right)\right.$, PDF \# 01-083-2372) are observed in the diffractogram of each thermally treated AAM. Formation of nepheline from hydroxysodalite has been previously observed between 600 and $800{ }^{\circ} \mathrm{C}$ in sodium silicate-activated metakaolin [48] and between 800 and $1000{ }^{\circ} \mathrm{C}$ in sodium silicateactivated fly ash [49]; formation of hydroxysodalite has been observed in silicate-activated fly ash cured at $40{ }^{\circ} \mathrm{C}$ [50], and this phase dehydrates between 400 and $630{ }^{\circ} \mathrm{C}$ [51]. It follows that the formation of both
Figure 5 Projection of alkali-activated material chemistry onto the (i) ternary $\mathrm{CaO}-\mathrm{Al}_{2} \mathrm{O}_{3}-\mathrm{SiO}_{2}$ system (neglecting $\mathrm{Na}_{2} \mathrm{O}$ content) and (ii) ternary $\mathrm{Na}_{2} \mathrm{O}-\mathrm{Al}_{2} \mathrm{O}_{3}-\mathrm{SiO}_{2}$ system (neglecting $\mathrm{CaO}$ content) showing elemental composition of AAM cured for 14 days for samples A-F as marked, as determined by SEM-EDX analysis. An evenly distributed selection of points across a representative $400 \mu \mathrm{m} \times 400 \mu \mathrm{m}$ section of the sample were used for analysis. Approximate regions of C-S-H, C-(A)-S-H, C-(N)-AS-H and N-A-S-(H) determined from [11, 38, 57, 58]. Hypothetical reaction mixture compositions based solely on slag or fly ash, calculated using the composition of the activating solution discussed above, are provided for reference and are indicated by red triangles and green circles, respectively.

sodalite and nepheline in the samples here is likely to occur via successive dehydration of hydrosodalite and hydroxysodalite. Reflections attributed to wollastonite $\left(\mathrm{CaSiO}_{3}\right.$, monoclinic polymorph, PDF \# 04-010-2581) are present in XRD data for all thermally treated AAM, indicating the formation of this phase due to either decomposition of C-(A)-S-H at approximately $810^{\circ} \mathrm{C}$ [52-54] or devitrification of unreacted slag particles. Small traces of gehlenite $\left(\mathrm{Ca}_{2} \mathrm{Al}\left(\mathrm{AlSiO}_{7}\right), \mathrm{PDF} \#\right.$ 04-014-4683) are also observed in each AAM.

\section{Scanning electron microscopy/energy- dispersive X-ray spectroscopy}

The elemental composition of each sample as determined by SEM-EDX is reported in Fig. 5 . The elemental composition of each sample is comparable with that of alkali-activated slag and slag/fly ash blends [18, 21, 38] and exhibits a cluster of points within compositional regions associated with both $\mathrm{C}-(\mathrm{N})-\mathrm{A}-\mathrm{S}-\mathrm{H}$ gels containing varying $\mathrm{Ca}$ content and $\mathrm{N}-\mathrm{A}-\mathrm{S}-(\mathrm{H})$ gels. This indicates that the main reaction product in all samples is an intimate mixture of both C-(N)-A-S-H and N-A-S-(H) gels. Some data points also exhibit compositions of the precursors, suggesting remnant unreacted precursor particles are also present.

Increased $\mathrm{Si}$ content and increased $\mathrm{Na}$ content within the AAM reaction mixture results in increased formation of low-Ca C-(N)-A-S-H and N-A-S(H) gels; this occurs when either $\mathrm{Si}$ or $\mathrm{Na}$ content is increased while the other is held constant, and when both $\mathrm{Si}$ and $\mathrm{Na}$ content are increased at the same time. These trends are consistent with thermodynamic predictions [11, 55]; formation of a low-Ca 
(a) i $\quad \mathrm{SiO}_{2}$

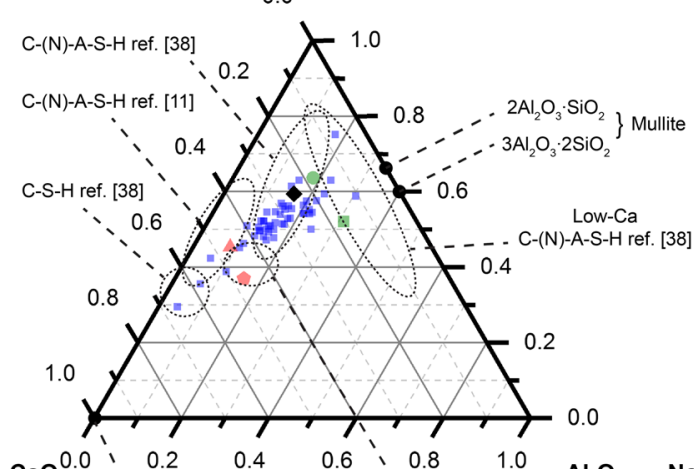

ii $\quad \mathrm{SiO}_{2}$

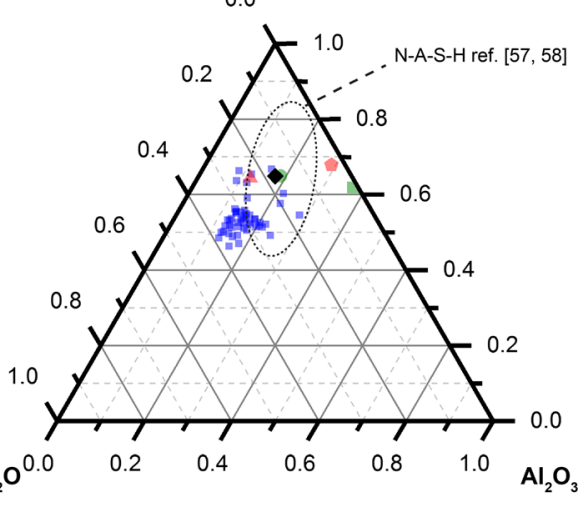

(b) Gypsum
$\mathrm{CaSO}_{4}-2 \mathrm{H}_{2} \mathrm{O}$

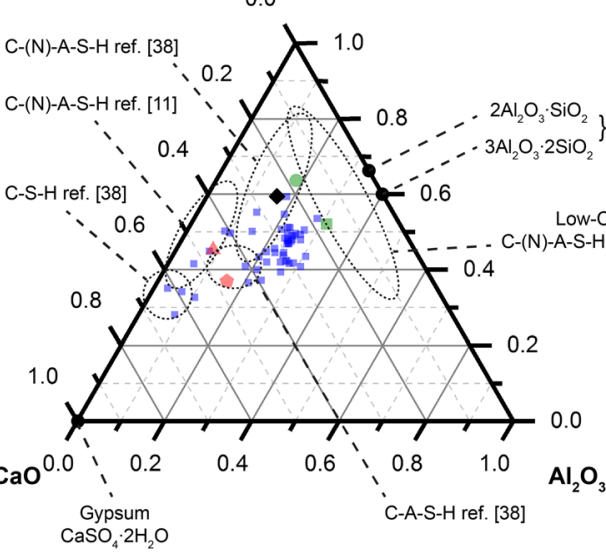

(c)
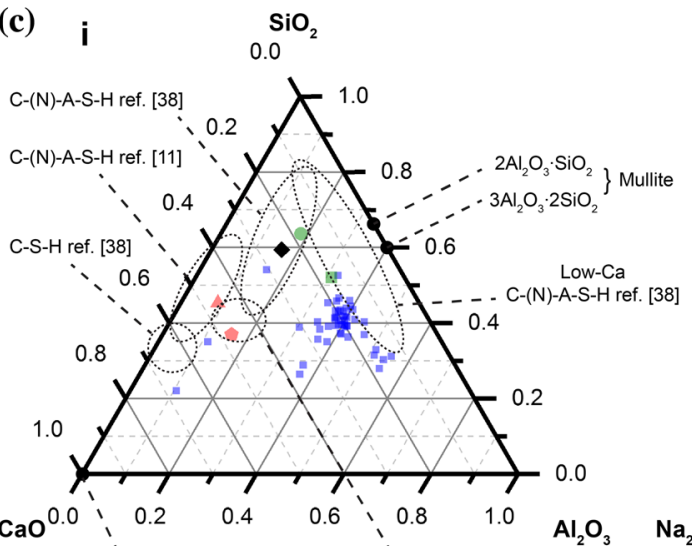

$\mathrm{CaO}^{0.0}: 0.2$ Gypsum $\mathrm{CaSO}_{4} \cdot 2 \mathrm{H}_{2} \mathrm{O}$ ii $\quad \mathrm{SiO}_{2}$

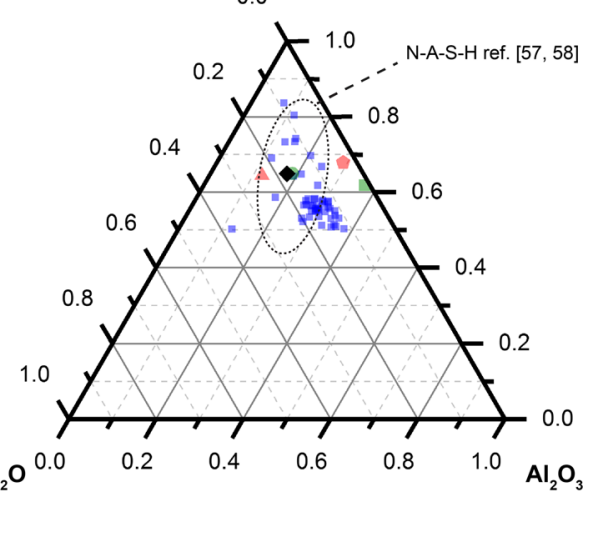

ii $\quad \mathrm{SiO}_{2}$

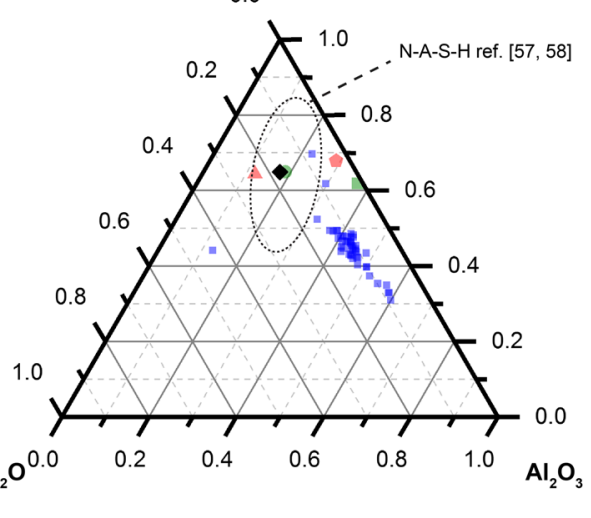

Cured 14 days

- $100 \%$ AAS Slag

$00 \%$ AAFA Fly ash 

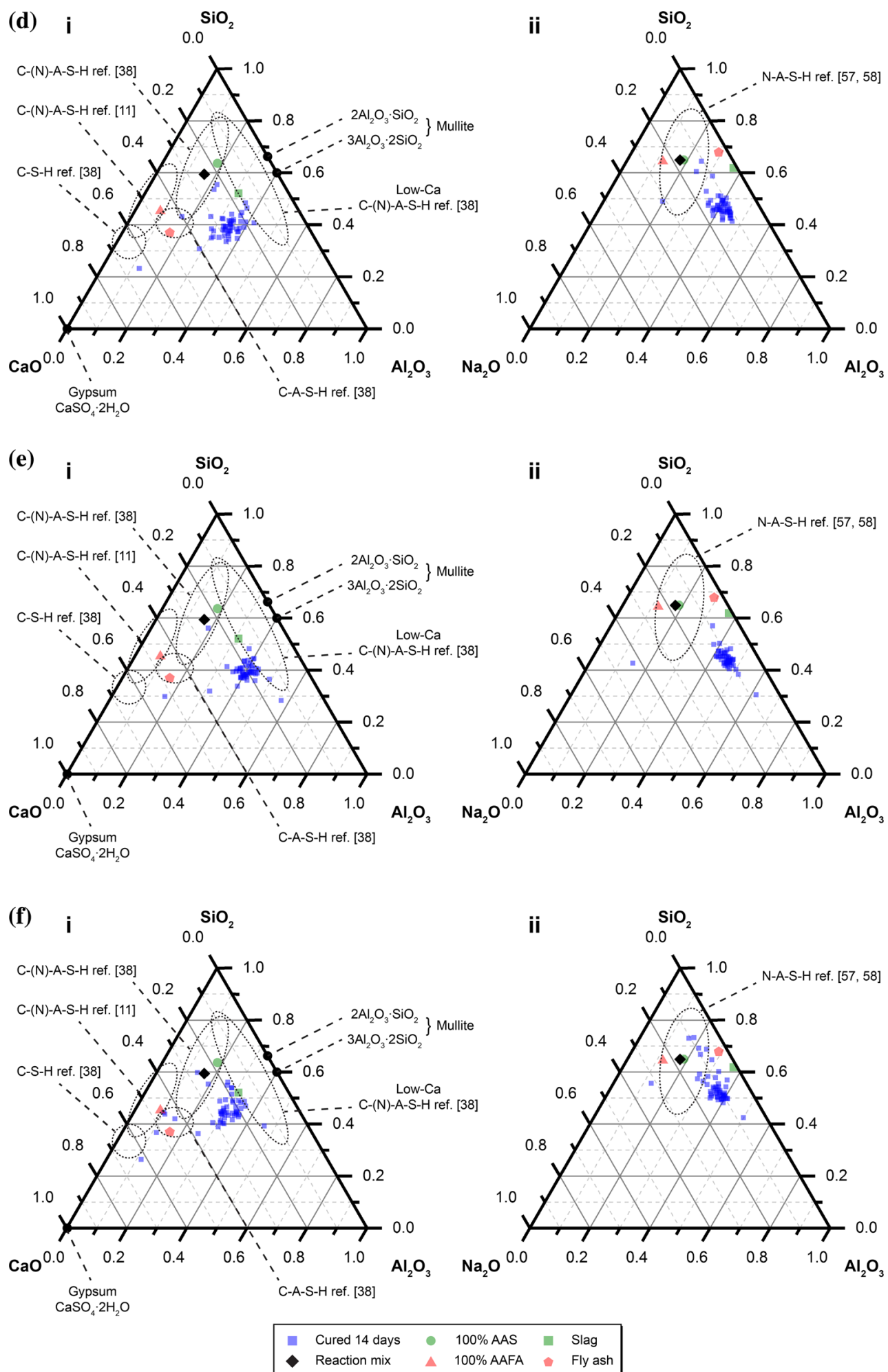

Figure 5 continued.

C-(N)-A-S-H gel will occur to the maximum $\mathrm{Al}$ and $\mathrm{Na}$ incorporation that is thermodynamically stable, with excess alkali and freely available $\mathrm{Si}$ and $\mathrm{Al}$ driving formation of N-A-S-(H) gel (observed explicitly by ${ }^{29}$ Si MAS NMR below). 
(a)

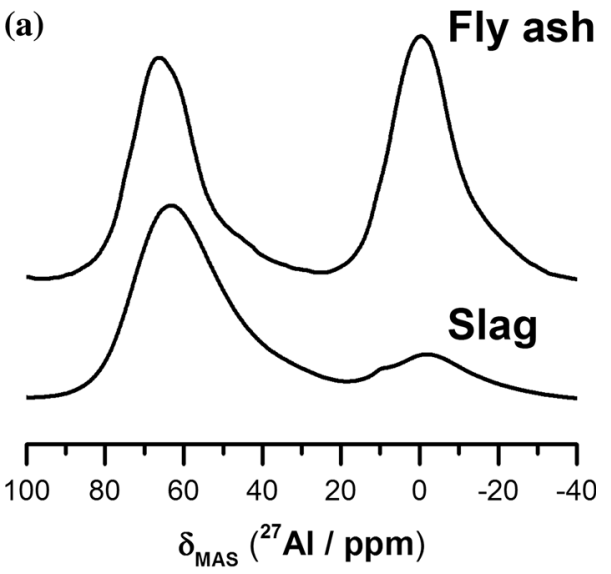

(b)
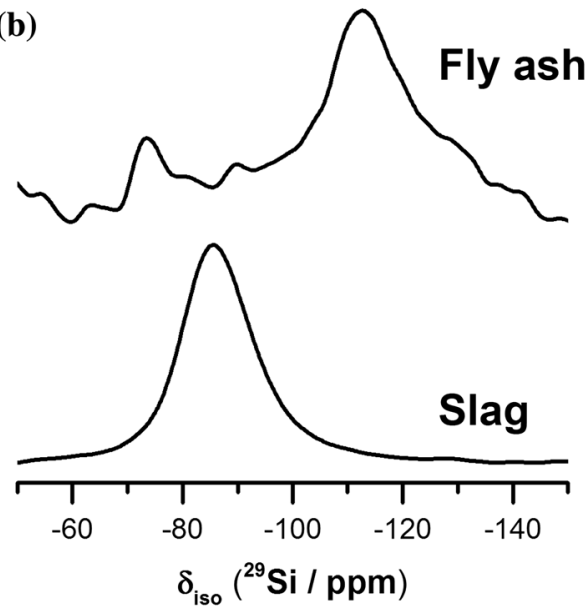

(c)

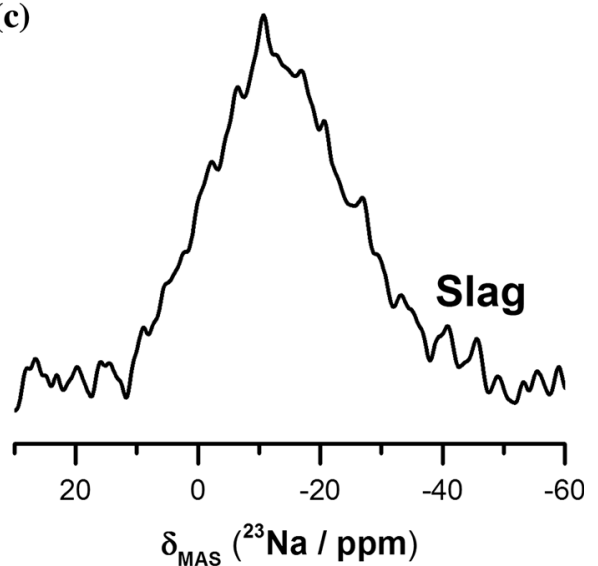

Figure 6 a ${ }^{27} \mathrm{Al}$ MAS $(8 \mathrm{kHz})$ NMR spectra, $\mathbf{b}{ }^{29} \mathrm{Si}$ MAS $(10 \mathrm{kHz})$ NMR spectra and $\mathbf{c}^{23} \mathrm{Na}$ MAS $(10 \mathrm{kHz})$ NMR spectra of fly ash and slag precursors.

Figure 5 shows that the elemental composition of each sample generally lies within a compositional region which suggests the formation of a moderateCa C-(N)-A-S-H gel reaction product. However, due to the intimate mixtures of C-(N)-A-S-H and N-A-S(H) gels observed previously in alkali-activated slag/ (a)

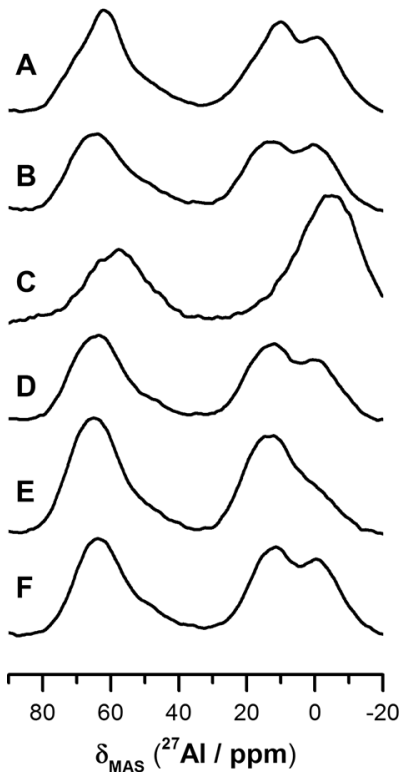

(b)

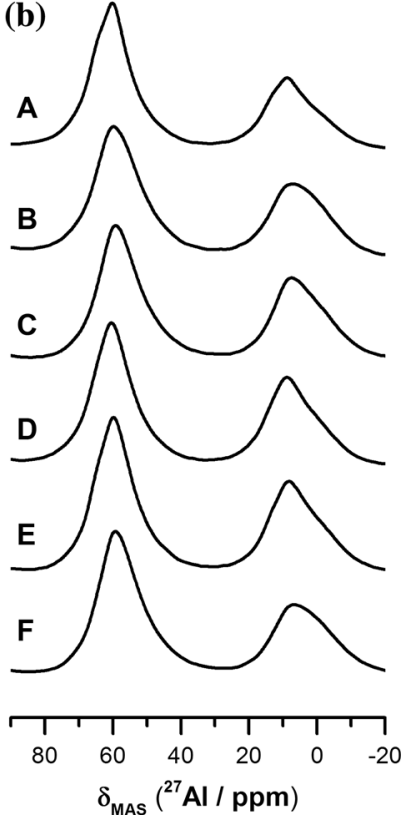

Figure $7{ }^{27} \mathrm{Al}$ MAS $(8 \mathrm{kHz})$ NMR spectra of a each AAM sample cured for 14 days and $\mathbf{b}$ each AAM cured for 14 days and heated to $1000{ }^{\circ} \mathrm{C}$.

fly ash blends $[18,21,38]$ and synthetic analogues [17], it is possible that the elemental composition of each data point represents the bulk composition of a mixture of high-Ca and low-Ca C-(N)-A-S-H, or of high-Ca and $\mathrm{N}-\mathrm{A}-(\mathrm{S})-\mathrm{H}$, if these phases are mixed on a scale smaller than the depth of X-ray generation for the accelerating voltage used $(15 \mathrm{kV})$ [56]. It is clear that the SEM-EDX analysis cannot resolve the individual C-(N)-A-S-H and N-A-S-(H) gels. Consequently, solid-state NMR spectroscopy has been used, with the results discussed in detail below.

\section{Solid-state magic angle spinning nuclear magnetic resonance spectroscopy}

\section{Precursors}

${ }^{27} \mathrm{Al},{ }^{29} \mathrm{Si}$ and ${ }^{23} \mathrm{Na}$ MAS NMR spectra of the slag and fly ash precursors are shown in Fig. $6 .{ }^{27} \mathrm{Al}$ MAS NMR spectra of slag exhibits a broad tetrahedral $\mathrm{AlO}_{4}$ resonance centred at approximately $\delta_{\text {obs }}=$ $63 \mathrm{ppm}$ consistent with the broad amorphous feature identified by $\mathrm{XRD}$, similar to previous ${ }^{27} \mathrm{Al}$ MAS NMR observations [18, 55, 59] and indicating extensive disorder and heterogeneity in the local structure and shielding experienced by $\mathrm{Al}$ in slag. A low- 
(a)

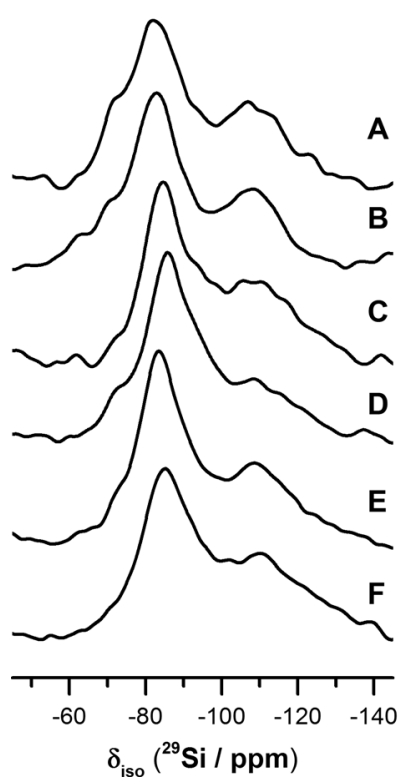

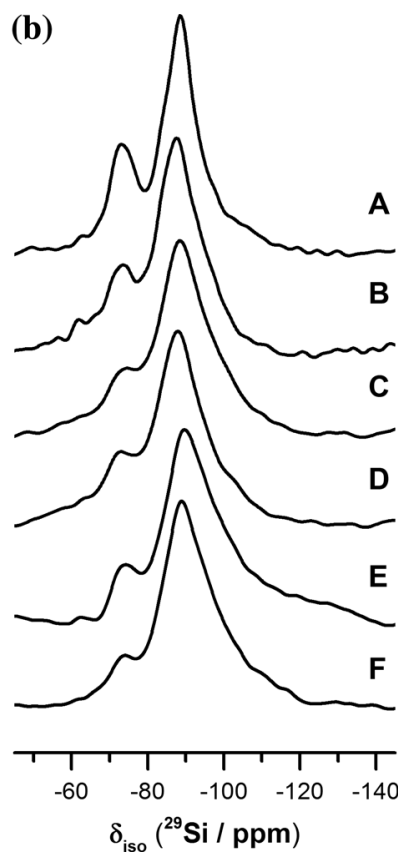

Figure $8{ }^{29} \mathrm{Si}$ MAS $(10 \mathrm{kHz})$ NMR spectra of a each AAM sample cured for 14 days and $\mathbf{b}$ each AAM cured for 14 days and heated to $1000{ }^{\circ} \mathrm{C}$.

intensity shoulder appears on this resonance at approximately $40 \mathrm{ppm}$, while two low-intensity octahedral $\mathrm{AlO}_{6}$ resonances are observed at $\delta_{\text {obs }}=$ - 2 ppm (broad) and 9 ppm (narrow). These resonances have previously been observed in slag but not attributed to a specific environment [18, 55, 59, 60]. The ${ }^{29} \mathrm{Si}$ MAS NMR spectra of slag exhibit a single broad resonance centred at $\delta_{\text {iso }}=-86 \mathrm{ppm}$ due to a distribution of $\mathrm{Q}^{\mathrm{n}}(\mathrm{mAl})$ (where $0 \leq m \leq n \leq 4$ ) environments dominated by species with lower polymerisation or higher $\mathrm{Al}$ substitution consistent with previous observations [18, 59]. The ${ }^{23} \mathrm{Na}$ MAS NMR spectrum for slag exhibits a single broad resonance centred at $\delta_{\text {obs }}=-12 \mathrm{ppm}$. The extensive shielding of ${ }^{23} \mathrm{Na}$ in the slag investigated here indicates its incorporation within the slag glass within a phase which exhibits greater electron density than if Na were phase separated.

The ${ }^{27} \mathrm{Al}$ MAS NMR spectrum of the fly ash also exhibits a broad tetrahedral $\mathrm{AlO}_{4}$ resonance centred at $\delta_{\text {obs }}=67 \mathrm{ppm}$ (with a low-intensity shoulder at $44 \mathrm{ppm}$ ) attributed to $\mathrm{Al}$ substituted in silicate glasses [61], as well as a high-intensity octahedral $\mathrm{AlO}_{6}$ resonance at $\delta_{\text {obs }}=0 \mathrm{ppm}$ attributed to $\mathrm{Al}$ in disordered mullite-like phases [62]. The ${ }^{29} \mathrm{Si}$ MAS NMR spectrum of the fly ash exhibits a broad resonance
Figure $9{ }^{29} \mathrm{Si}$ MAS $(10 \mathrm{kHz})$ NMR spectra (shown in black) of samples $\mathbf{a}-\mathbf{f}$ as marked with associated deconvolutions. In each case the fit (shown in red) is the sum of the deconvoluted peaks (peaks attributed to $\mathrm{Si}$ sites in $\mathrm{C}-(\mathrm{N})-\mathrm{A}-\mathrm{S}-\mathrm{H}$ are shown in blue, peaks attributed to $\mathrm{Si}$ sites in N-A-S-(H) are shown in green). The overall contribution of the unreacted precursor is shown in grey (individual peaks attributed to the unreacted precursor are not shown for clarity).

centred at approximately $\delta_{\text {iso }}=-112 \mathrm{ppm}$ and attributed to a distribution of $\mathrm{Q}^{4}(\mathrm{mAl})$ sites within the amorphous component (consistent with the broad feature identified for this sample by XRD). Si sites within mullite in fly ash (identified by XRD) also resonate at $\delta_{\text {iso }}=-87 \mathrm{ppm}$ and $-106 \mathrm{ppm}$ [62], while those in quartz contribute to the spectrum at approximately $\delta_{\text {iso }}=-112 \mathrm{ppm}[63,64] .{ }^{23} \mathrm{Na}$ MAS NMR data could not be obtained for fly ash due to the low sodium content $\left(0.81 \mathrm{wt} \% \quad \mathrm{Na}_{2} \mathrm{O}\right)$ and severe signal dampening caused by the high content of paramagnetic $\mathrm{Fe}_{2} \mathrm{O}_{3}$ species (13.16 wt \%).

\section{Alkali-activated materials}

${ }^{27}$ Al MAS NMR of as-cured alkali-activated materials A broad resonance centred at $\delta_{\text {obs }} 65 \mathrm{ppm}$ is observed in the ${ }^{27} \mathrm{Al}$ MAS NMR spectra of each AAM (Fig. 7) and is assigned to $\mathrm{Al}$ in significantly distorted tetrahedral environments within poorly crystalline $\mathrm{C}-(\mathrm{N})-$ A-S-H and amorphous N-A-S-(H) gel products $[18,65,66]$ as well as unreacted slag and fly ash. Two distinct octahedral $\mathrm{Al}$ environments are indicated by broad overlapping resonances at approximately $\delta_{\text {obs }}$ $=14$ and 0 ppm in all AAM samples. The resonance at $0 \mathrm{ppm}$ is attributed to octahedral $\mathrm{Al}$ in disordered mullite-like phases in remnant fly ash particles, while that at $14 \mathrm{ppm}$ is likely to be due to contributions from $\mathrm{Al}^{\mathrm{VI}}$ sites within remnant slag particles. Small variations in the shielding of both tetrahedral and octahedral resonances are observed between samples as a consequence of structural differences due to variations in composition and crystallinity.

\section{${ }^{27}$ Al MAS NMR of thermally treated alkali-activated} materials ${ }^{27} \mathrm{Al}$ MAS NMR spectra of each thermally treated AAM (Fig. 7) are similar to those of samples prior to heating, with the broad tetrahedral Al resonance (now centred at $\delta_{\text {obs }}=-59 \mathrm{ppm}$ ) sharpening and increasing in intensity. This is attributed to contributions from resonances of tetrahedral $\mathrm{Al}$ within 

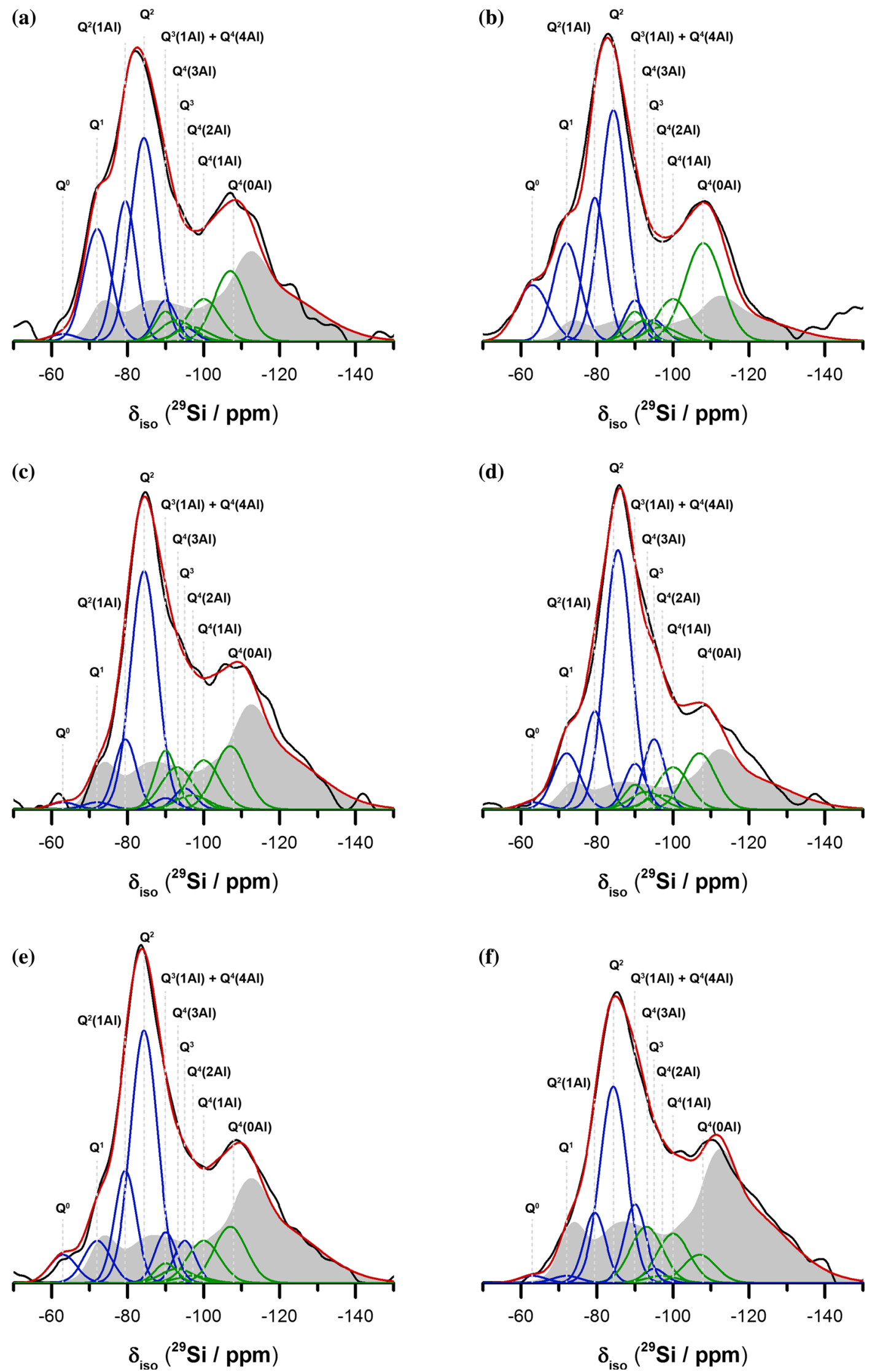
sodalite and nepheline [67]. The two distinct octahedral $\mathrm{Al}$ resonances present in the ${ }^{27} \mathrm{Al}$ MAS NMR of samples prior to heating can no longer be observed, replaced by a single broad octahedral resonance of lower intensity at approximately $\delta_{\mathrm{obs}}=8 \mathrm{ppm}$. The lineshape of this resonance suggests it could contain contributions from both octahedral $\mathrm{Al}$ resonances observed in the ${ }^{27} \mathrm{Al}$ MAS NMR of samples prior to heating, while the sharpening of these resonances is consistent with partial crystallisation of the amorphous material in the AAM observed by XRD. No significant variation in the spectra is observed between samples indicating strong structural similarity in Al-containing sites.

${ }^{29} \mathrm{Si}$ MAS NMR of as-cured alkali-activated materials The ${ }^{29}$ Si MAS NMR spectra for each AAM before and after heat treatment are shown in Fig. 8. A broad resonance at approximately $\delta_{\text {iso }}=-83 \mathrm{ppm}$ is observed in the spectra of all samples. Chemical shifts of $\mathbf{Q}^{n}(m \mathrm{Al})$ species in these samples are expected to overlap significantly due to shielding by network modifying cations $[68,69]$ and the presence of $\mathrm{Al}(\mathrm{VI})$ species [70].

Spectral deconvolutions (Fig. 9) are summarised in Table 4. ${ }^{29}$ Si MAS NMR spectra were deconvoluted by fitting the minimum number of Gaussian peaks to provide an accurate and meaningful interpretation of the spectra and maintain consistency with structural constraints for a C-(N)-(A)-S-H gel described by the 'Crosslinked Substituted Tobermorite Model' (CSTM)
[11] and a statistical distribution of $\mathrm{Si}$ and $\mathrm{Al}$ sites within a $\mathrm{Q}^{4}$ aluminosilicate network [18, 42]. Peak positions and widths were held constant throughout all spectral deconvolutions except where noted. Component peaks attributed to remnant precursor particles were rescaled by a single factor, i.e. congruent dissolution of the precursors was assumed in all cases.

Upon alkali-activation six new Si environments are observed in each sample, indicated by resonances at approximately $\delta_{\text {iso }}=-63.0,-72.0,-79.4,-84.3$, - 90.0 and - $95.0 \mathrm{ppm}$, attributed to $\mathrm{Q}^{0}, \mathrm{Q}^{1}, \mathrm{Q}^{2}(1 \mathrm{Al})$, $\mathrm{Q}^{2}, \mathrm{Q}^{3}(1 \mathrm{Al})$, and $\mathrm{Q}^{3}$, respectively. These resonances are attributed to $\mathrm{Si}$ environments within a crosslinked C-(N)-A-S-H gel [11, 12, 18, 60]. The peak at - $90 \mathrm{ppm}$ is assigned to both $\mathrm{Q}^{3}(1 \mathrm{Al})$ and $\mathrm{Q}^{4}(4 \mathrm{Al})$ sites as both environments exhibit overlapping resonances within this region [71]. $\mathrm{Q}^{3}$ and $\mathrm{Q}^{4}(3 \mathrm{Al})$ also exhibit overlapping resonances, however, in order to maintain consistency with the structural constraints for a mixed crosslinked/non-crosslinked C-(N)-(A)S-H gel described by the CSTM a separate peak for $\mathrm{Q}^{4}(3 \mathrm{Al})$ at -93 ppm must be fitted to account for the additional intensity above what is provided by the $Q^{3}$ resonance at - $95 \mathrm{ppm}$. Consequently, the formation of $\mathrm{Q}^{4}(4 \mathrm{Al})$ and $\mathrm{Q}^{4}(3 \mathrm{Al})$ sites is also observed upon alkali activation of all samples and attributed to a polymerised Al-rich aluminosilicate phase. This provides explicit evidence of formation of an additional N-A-S-(H) phase within these blended systems.
Table 4 Summary of $\mathrm{Q}^{\mathrm{n}}(m \mathrm{Al})$ Si coordination environments within the reaction product (i.e. neglecting the contribution of remnant precursors) identified in the deconvoluted ${ }^{29} \mathrm{Si}$ MAS NMR spectra for each AAM

\begin{tabular}{lrrrrrr}
\hline & \multicolumn{7}{c}{ Normalised reaction product site percentages } & \\
\cline { 2 - 6 } Sample & $\mathrm{A}$ & $\mathrm{B}$ & $\mathrm{C}$ & $\mathrm{D}$ & $\mathrm{E}$ & $\mathrm{F}$ \\
\hline $\mathrm{Q}^{0}$ & 1 & 8 & 1 & 1 & 4 & 1 \\
$\mathrm{Q}^{1}$ & 17 & 12 & 1 & 8 & 7 & 1 \\
$\mathrm{Q}^{2}(1 \mathrm{Al})$ & 17 & 14 & 10 & 12 & 14 & 11 \\
$\mathrm{Q}^{2}$ & 30 & 28 & 41 & 39 & 39 & 39 \\
$\mathrm{Q}^{3}(1 \mathrm{Al})$ & 2 & 2 & 3 & 8 & 5 & 2 \\
$\mathrm{Q}^{3}$ & 5 & 4 & 2 & 5 & 6 & 0 \\
Total C-(N)-A-S-H gel products & 70 & 69 & 57 & 74 & 75 & 55 \\
$\mathrm{Q}^{4}(4 \mathrm{Al})$ & 3 & 3 & 8 & 3 & 2 & 12 \\
$\mathrm{Q}^{4}(3 \mathrm{Al})$ & 4 & 3 & 9 & 3 & 3 & 13 \\
$\mathrm{Q}^{4}(2 \mathrm{Al})$ & 2 & 2 & 3 & 3 & 1 & 2 \\
$\mathrm{Q}^{4}(1 \mathrm{Al})$ & 7 & 6 & 10 & 8 & 8 & 12 \\
$\mathrm{Q}^{4}(0 \mathrm{Al})$ & 12 & 17 & 13 & 10 & 10 & 7 \\
Total N-A-S-(H) gel products & 30 & 31 & 43 & 26 & 25 & 45 \\
\hline
\end{tabular}

The uncertainty was estimated from the noise in each spectrum. The estimated uncertainty in absolute site percentages is $\pm 2 \%$ 
(a)

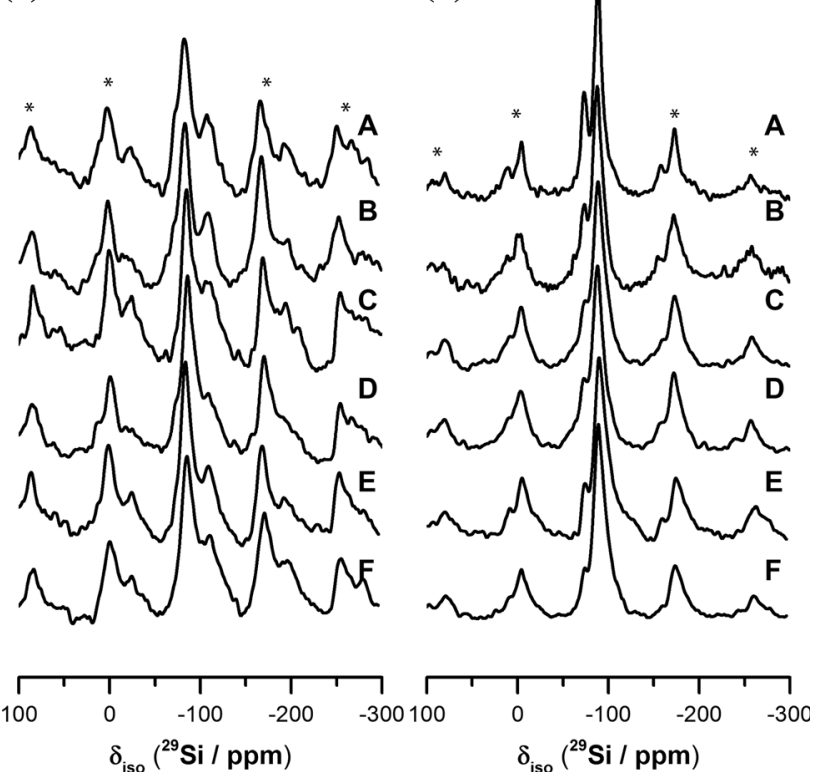

Figure $10{ }^{29} \mathrm{Si}$ MAS $(10 \mathrm{kHz})$ NMR spectra showing the spectral region from 100 to $-300 \mathrm{ppm}$ of a each AAM sample cured for 14 days and $\mathbf{b}$ each AAM cured for 14 days and heated to $1000{ }^{\circ} \mathrm{C}$. Spinning side bands are indicated by $*$.

Quantification of the intensity of each individual $\mathrm{Si}$ site can be used to determine the relative amount of each gel present in each sample, providing insight into the mechanisms which dictate thermally induced nanostructural changes. Quantification of the intensity of the $\mathrm{Q}^{4}(4 \mathrm{Al})$ site $\left(\mathrm{I}_{\mathrm{Q}^{4}(4 \mathrm{Al})}\right)$ can be performed by assuming $\mathrm{Q}^{4}(m \mathrm{Al})$ sites are present in an additional Al-rich phase separate from the C-(N)-(A)-S-H gel and using Eq. (1), where $\mathrm{I}_{\mathrm{Q}^{4}(3 \mathrm{Al})}$ is the intensity of the $\mathrm{Q}^{4}(3 \mathrm{Al})$ resonance determined from deconvolution of the ${ }^{29} \mathrm{Si}$ MAS NMR data, and $\mathrm{Si} / \mathrm{Al}$ is the $\mathrm{Si} / \mathrm{Al}$ ratio for the additional $\mathrm{Q}^{4}(m \mathrm{Al})$ phase, which is assumed to be 1.2, consistent with the composition of N-A-S(H) gels in alkali-activated metakaolin [72], statistical thermodynamic model predictions [42] and a generalised structural description of the additional N-A-S$(\mathrm{H})$ gel reaction product formed in alkali-activated slag containing biphasic C-(N)-A-S-H/N-A-S-(H) gel blends from ${ }^{29} \mathrm{Si}$ and ${ }^{27} \mathrm{Al}$ MAS NMR data [11]. Formation of four new $\mathrm{Si}$ environments indicated by peaks at approximately $\delta_{\text {iso }}=-90.0,-93.0,-97.0$, -100.0 and $-107.0 \mathrm{ppm}$, attributed to $\mathrm{Q}^{4}(4 \mathrm{Al})$, $\mathrm{Q}^{4}(3 \mathrm{Al}), \mathrm{Q}^{4}(2 \mathrm{Al}), \mathrm{Q}^{4}(1 \mathrm{Al})$ and $\mathrm{Q}^{4}(0 \mathrm{Al})$, respectively, within a N-A-S-(H) gel are observed. Tricalcium silicate exhibits a ${ }^{29} \mathrm{Si}$ MAS NMR resonance with maximum intensity at approximately $\delta_{\text {iso }}=-73 \mathrm{ppm}$ (a)

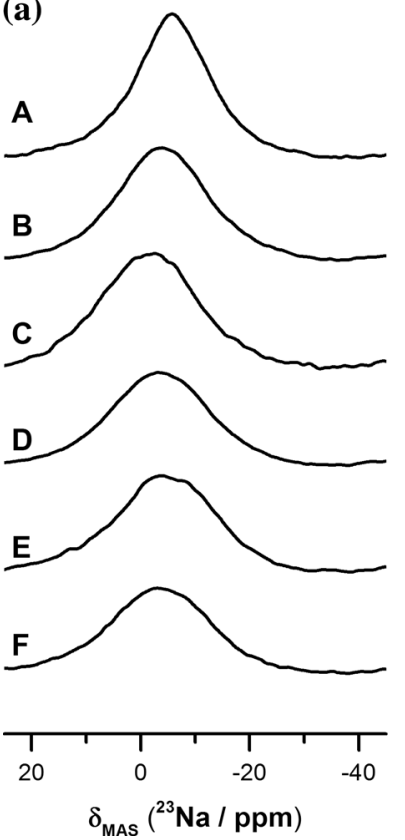

(b)

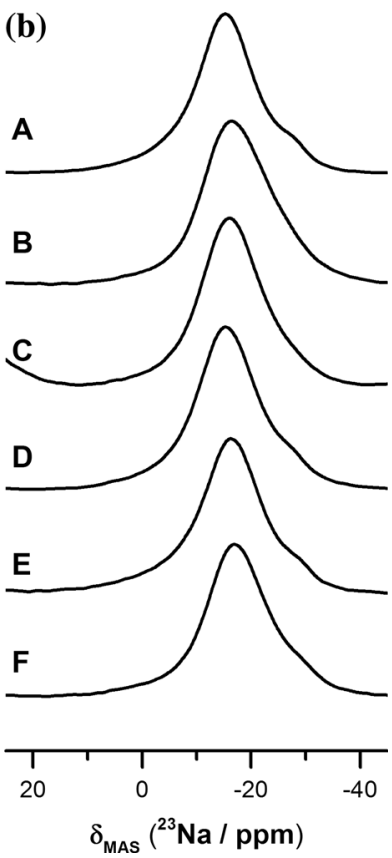

Figure $11{ }^{23} \mathrm{Na}$ MAS $(10 \mathrm{kHz})$ NMR spectra of a each AAM sample cured for 14 days and $\mathbf{b}$ each AAM cured for 14 days and heated to $1000{ }^{\circ} \mathrm{C}$.

$[73,74]$ and will consequently contribute to the ${ }^{29} \mathrm{Si}$ MAS NMR resonance assigned to $Q^{1}$ species in the as-cured alkali-activated materials.

$\mathrm{I}_{\mathrm{Q}^{4}(4 \mathrm{Al})}=\mathrm{I}_{\mathrm{Q}^{4}(3 \mathrm{Al})}\left[\frac{\frac{3}{5}(\mathrm{Si} / \mathrm{Al}-1)}{1-(\mathrm{Si} / \mathrm{Al})}\right]$

${ }^{29}$ Si MAS NMR of thermally treated alkali-activated materials Heating each AAM sample to $1000{ }^{\circ} \mathrm{C}$ results in the formation of a broad, high-intensity resonance with a maximum at approximately $\delta_{\text {iso }}=$ $-88 \mathrm{ppm}$ as well as a low-intensity resonance at approximately $\delta_{\text {iso }}=-73 \mathrm{ppm}$. Spectral deconvolution was not possible for the ${ }^{29} \mathrm{Si}$ MAS NMR spectra of the thermally treated AAM due to the formation of multiple crystalline phases during thermal treatment and the consequent absence of suitable constraints on the deconvolution. Despite this, important insights may be obtained from the resonances in these spectra.

The broad resonance at -88 ppm contains contributions from resonances at approximately $\delta_{\text {iso }}=-85$, $-92,-102$ and $-100 \mathrm{ppm}$ (indicated by distinct shoulders on the main ${ }^{29} \mathrm{Si}$ MAS NMR resonance). This broad resonance results from contributions from crystalline phases identified by XRD. Nepheline 
comprises two distinct $\mathrm{Q}^{4}(4 \mathrm{Al})$ sites (resonating at $\delta_{\text {iso }}=-85$ and $-88 \mathrm{ppm}$, respectively), one $\mathrm{Q}^{4}(3 \mathrm{Al})$ site resonating at $\delta_{\text {iso }}=-92 \mathrm{ppm}$ and one $\mathrm{Q}^{4}(0 \mathrm{Al})$ resonating at $\delta_{\text {iso }}=-102 \mathrm{ppm}[75,76]$. Sodalite exhibits a single ${ }^{29} \mathrm{Si}$ MAS NMR resonance at $\delta_{\text {iso }}=$ - 85 ppm corresponding to a $\mathrm{Q}^{4}(4 \mathrm{Al})$ site [77], while tricalcium silicate exhibits a ${ }^{29} \mathrm{Si}$ MAS NMR resonance with maximum intensity at approximately $\delta_{\text {iso }}$ $=-73 \mathrm{ppm}[73,74]$ and is responsible for the resonance at this position in the ${ }^{29} \mathrm{Si}$ MAS NMR spectra of the thermally treated alkali-activated materials. Si sites within wollastonite are expected to resonate at approximately $\delta_{\text {iso }}=-87.8,-89.0$ and $-89.5 \mathrm{ppm}$, and will contribute to the ${ }^{29} \mathrm{Si}$ MAS NMR spectra at these positions [78].

As discussed above, $\mathrm{Si}$ sites within mullite in remnant fly ash particles (identified by XRD) are expected to resonate at $\delta_{\text {iso }}=-87$ and $-106 \mathrm{ppm}$ [62], while those in quartz are expected to contribute to the spectrum at approximately $\delta_{\text {iso }}=-112 \mathrm{ppm}$ $[63,64]$. Strong reflections attributed to these phases are identified in XRD data for these samples; these phases are deemed responsible for the resonances in this region of each spectrum.

Transferral of the ${ }^{29} \mathrm{Si}$ MAS NMR signal to spinning sidebands, dampening and broadening of the central resonance occurs to a much greater extent in the spectra of AAM samples prior to heating than those heated to $1000{ }^{\circ} \mathrm{C}$ (Fig. 10). This suggests oxidation of paramagnetic $\mathrm{Fe}(\mathrm{III})$ in $\mathrm{Fe}_{2} \mathrm{O}_{3}$ (identified as hematite in XRD data for AAM samples prior to heating) to ferrimagnetic $\mathrm{Fe}(\mathrm{II}, \mathrm{III})$ in $\mathrm{Fe}_{3} \mathrm{O}_{4}$ (identified as magnetite in XRD data for AAM samples heated to $1000{ }^{\circ} \mathrm{C}$ ), with the reduction in paramagnetic ions reducing transferral of the signal from the central resonance to spinning sidebands. Beyond this change in oxidation state, however, $\mathrm{Fe}$ does not appear to influence the thermal performance of these materials, despite the reasonably high amount of $\mathrm{Fe}$ in these materials ( $\sim 8 \mathrm{wt} \%$ in the binder).

Previous work has shown increased alkali content and lower $\mathrm{Si} / \mathrm{Al}$ ratio results in enhanced strength retention after thermal treatment in the alkali-activated slag/fly ash blends investigated here (i.e. samples of the same composition) [6]. Samples with increased alkali content in the present study exhibited higher amounts of the additional N-A-S-(H) reaction product, due to the structural limitations on $\mathrm{Al}$ substitution within C-(N)-A-S-H gels (which can only incorporate $\mathrm{Al}$ within bridging tetrahedral sites) [11] and absence of Ca-rich AFm phases [17]. These samples will consequently contain lower amounts of bound structural water, experience reduced water loss and reduced internal water vapour pressure at high temperatures compared to those with lower formation of N-A-S- $(\mathrm{H})[8,9]$. These nanostructural features will result in reduced stresses within the AAM at high temperatures and explain the enhanced thermal performance observed for samples exhibiting higher N-A-S-(H) gel formation.

\section{${ }^{23} \mathrm{Na} M A S \mathrm{NMR}$}

The ${ }^{23} \mathrm{Na}$ MAS NMR spectra for each AAM exhibit a single broad resonance centred at approximately $\delta_{\text {obs }}$ $=-3 \mathrm{ppm}$ (Fig. 11) attributed to $\mathrm{Na}^{+}$cations associated with aluminium-centred tetrahedra, playing a charge-balancing role within the C-(N)-A-S-H $[66,79]$ and N-A-S-(H) gel frameworks [31, 80]. Little variation in Na sites is observed between samples, and the broad nature of the resonance spanning from 20 to - 20 ppm indicates an extensive disorder in Na sites within the AAM. ${ }^{23} \mathrm{Na}$ MAS NMR spectra of each AAM heated to $1000{ }^{\circ} \mathrm{C}$ display a single broad resonance centred at approximately $\delta_{\text {obs }}=-16 \mathrm{ppm}$ and attributed to Na sorbed to the surfaces of the nanostructured gels [17] as a consequence of gel dehydration during heating. This resonance also exhibits a low-intensity shoulder at approximately $\delta_{\text {obs }}=$ $-27 \mathrm{ppm}$ that is most pronounced at higher $\mathrm{Na}$ content $(\mathrm{Na} / \mathrm{Al} \geq 1)$. This broad resonance contains contributions from nepheline at between $\delta_{\text {obs }}=-4$ and $-28 \mathrm{ppm}$, centred at approximately $\delta_{\text {obs }}=$ - 15 ppm (9.4 (T) [81] (the formation of which is expected to be promoted by higher bulk Na content), as well as from sodalite at approximately $\delta_{\text {obs }}=$ - 11 ppm [77, 82].

\section{Conclusions}

The key nanostructural changes occurring in a series of AAM based on blends of slag and fly ash precursors during exposure to temperatures up to $1000{ }^{\circ} \mathrm{C}$ were investigated by application of X-ray diffraction (XRD), scanning electron microscopy (SEM) coupled with X-ray energy-dispersive spectroscopy (EDX) and multinuclear solid-state nuclear magnetic resonance (NMR) spectroscopy probing ${ }^{29} \mathrm{Si},{ }^{27} \mathrm{Al},{ }^{23} \mathrm{Na}$ nuclei. Each AAM comprised primarily of a 
disordered C-(N)-A-S-H-type gel, with at least some degree of crosslinking, as well as a disordered N-A-S(H)-type gel. After heating to $1000{ }^{\circ} \mathrm{C}$ each AAM experienced devitrification of these disordered gels and formation of sodalite, nepheline and wollastonite. Samples with increased alkali content exhibit higher formation of an additional N-A-S-(H) reaction product due to the structural limitations on $\mathrm{Al}$ substitution within the C-(N)-A-S-H gel and absence of Ca-rich AFm phases [17]. These samples will consequently contain lower amounts of bound structural water, experience reduced water loss and reduced internal water vapour pressure at high temperatures. These nanostructural features will result in reduced stresses within the AAM at high temperatures and explain the enhanced strength after thermal treatment observed for these materials previously. This provides insight into thermally induced changes to gel atomic structure of C-(N)-A-S-H/N-A-S-(H) gel blends which are fundamental for the development of fire-resistant construction materials.

\section{Acknowledgements}

This project was funded by the Australian Research Council (ARC), including support through an ARC Linkage Project (Grant number: LP140100504) and through the ARC Centre for Advanced Manufacturing of Prefabricated Housing. XRD data were acquired at the Materials Characterisation and Fabrication Platform (MCFP), The University of Melbourne, and the Victorian Node of the Australian National Fabrication Facility (ANFF). The authors thank Professor John L. Provis, The University of Sheffield, for very insightful discussions regarding this work.

\section{Compliance with ethical standards}

Conflict of interest The authors declare that they have no conflict of interest.

Open Access This article is distributed under the terms of the Creative Commons Attribution 4.0 International License (http://creativecommons.org/ licenses/by/4.0/), which permits unrestricted use, distribution, and reproduction in any medium, provided you give appropriate credit to the original author(s) and the source, provide a link to the
Creative Commons license, and indicate if changes were made.

\section{References}

[1] Provis JL, Palomo A, Shi C (2015) Advances in understanding alkali-activated materials. Cem Concr Res 78A:110-125

[2] Vickers L, van Riessen A, Rickard WDA (2014) Fire-resistant geopolymers: role of fibres and fillers to enhance thermal properties. Springer, Singapore

[3] Barbosa VFF, MacKenzie KJD (2003) Thermal behaviour of inorganic geopolymers and composites derived from sodium polysialate. Mater Res Bull 38:319-331

[4] Zhao R, Sanjayan JG (2011) Geopolymer and Portland cement concretes in simulated fire. Mag Concr Res 63:163-173

[5] Kong DL, Sanjayan JG (2010) Effect of elevated temperatures on geopolymer paste, mortar and concrete. Cem Concr Res 40:334-339

[6] Kashani A, Ngo TD, Walkley B, Mendis P (2017) Thermal performance of calcium-rich alkali-activated materials: a microstructural and mechanical study. Constr Build Mater 153:225-237

[7] Rivera OG, Long WR, Weiss CA Jr, Moser RD, Williams BA, Torres-Cancel K, Gore ER, Allison PG (2016) Effect of elevated temperature on alkali-activated geopolymeric binders compared to portland cement-based binders. Cem Concr Res 90:43-51

[8] Mendes A, Sanjayan J, Collins F (2008) Phase transformations and mechanical strength of OPC/Slag pastes submitted to high temperatures. Mater Struct 41:345-350

[9] Hertz KD (2005) Concrete strength for fire safety design. Mag Concr Res 57:445-453

[10] Schilling PJ, Butler LG, Roy A, Eaton HC (1994) ${ }^{29} \mathrm{Si}$ and ${ }^{27}$ AI MAS-NMR of $\mathrm{NaOH}$-activated blast-furnace slag. J Am Ceram Soc 77:2363-2368

[11] Myers RJ, Bernal SA, San Nicolas R, Provis JL (2013) Generalized structural description of calcium-sodium aluminosilicate hydrate gels: the cross-linked substituted tobermorite model. Langmuir 29:5294-5306

[12] Richardson IG (2008) The calcium silicate hydrates. Cem Concr Res 38:137-158

[13] Provis JL, Lukey GC, van Deventer JSJ (2005) Do geopolymers actually contain nanocrystalline zeolites? A reexamination of existing results. Chem Mater 17:3075-3085 
[14] Bernal SA, Provis JL, Rose V, de Gutierrez RM (2011) Evolution of binder structure in sodium silicate-activated slag-metakaolin blends. Cem Concr Compos 33:46-54

[15] Yip CK, Lukey GC, Provis JL, van Deventer JSJ (2008) Effect of calcium silicate sources on geopolymerisation. Cem Concr Res 38:554-564

[16] Yip CK, Van Deventer JSJ (2003) Microanalysis of calcium silicate hydrate gel formed within a geopolymeric binder. J Mater Sci 38:3851-3860. https://doi.org/10.1023/A: 1025904905176

[17] Walkley B, San Nicolas R, Sani M-A, Rees GJ, Hanna JV, van Deventer JSJ, Provis JL (2016) Phase evolution of C-(N)-A-S-H/N-A-S-H gel blends investigated via alkaliactivation of synthetic calcium aluminosilicate precursors. Cem Concr Res 89:120-135

[18] Bernal SA, Provis JL, Walkley B, San Nicolas R, Gehman JD, Brice DG, Kilcullen AR, Duxson P, van Deventer JSJ (2013) Gel nanostructure in alkali-activated binders based on slag and fly ash, and effects of accelerated carbonation. Cem Concr Res 53:127-144

[19] Myers RJ, Bernal SA, Provis JL (2014) A thermodynamic model for C-(N-)A-S-H gel: CNASH_ss. Derivation and validation. Cem Concr Res 66:27-47

[20] Bernal SA, Rodriguez ED, de Gutierrez RM, Gordillo M, Provis JL (2011) Mechanical and thermal characterisation of geopolymers based on silicate-activated metakaolin/slag blends. J Mater Sci 46:5477-5486. https://doi.org/10.1007/ s10853-011-5490-z

[21] Ismail I, Bernal SA, Provis JL, San Nicolas R, Hamdan S, van Deventer JSJ (2014) Modification of phase evolution in alkali-activated blast furnace slag by the incorporation of fly ash. Cem Concr Compos 45:125-135

[22] Yip CK, Lukey GC, van Deventer JSJ (2005) The coexistence of geopolymeric gel and calcium silicate hydrate at the early stage of alkaline activation. Cem Concr Res 35:1688-1697

[23] Provis JL, Bernal SA (2014) Geopolymers and related alkaliactivated materials. Annu Rev Mater Res 44:299-327

[24] Gartner EM, Macphee DE (2011) A physico-chemical basis for novel cementitious binders. Cem Concr Res 41:736-749

[25] García-Lodeiro I, Palomo A, Fernández-Jiménez A, Macphee DE (2011) Compatibility studies between N-A-S-H and C-A-S-H gels. Study in the ternary diagram $\mathrm{Na}_{2} \mathrm{O}-\mathrm{CaO}-$ $\mathrm{Al}_{2} \mathrm{O}_{3}-\mathrm{SiO}_{2}-\mathrm{H}_{2} \mathrm{O}$. Cem Concr Res 41:923-931

[26] Ali F, Nadjai A, Talamona D (2004) Assessment of the susceptibility of normal and high strength concrete for explosive spalling. J Appl Fire Sci 13:79-88

[27] Ali F, O'Connor D, Abu-Tair A (2001) Explosive spalling of high-strength concrete columns in fire. Mag Concr Res 53:197-204
[28] Kong DL, Sanjayan JG, Sagoe-Crentsil K (2007) Comparative performance of geopolymers made with metakaolin and fly ash after exposure to elevated temperatures. Cem Concr Res 37:1583-1589

[29] Kong DL, Sanjayan JG (2008) Damage behavior of geopolymer composites exposed to elevated temperatures. Cem Concr Compos 30:986-991

[30] Kong DL, Sanjayan JG, Sagoe-Crentsil K (2008) Factors affecting the performance of metakaolin geopolymers exposed to elevated temperatures. J Mater Sci 43:824-831. https://doi.org/10.1007/s10853-007-2205-6

[31] Walkley B, San Nicolas R, Sani MA, Gehman JD, van Deventer JS, Provis JL (2016) Phase evolution of $\mathrm{Na}_{2} \mathrm{O}$ $\mathrm{Al}_{2} \mathrm{O} 3-\mathrm{SiO}_{2}-\mathrm{H}_{2} \mathrm{O}$ gels in synthetic aluminosilicate binders. Dalton Trans 45:5521-5535

[32] Hajimohammadi A, Provis JL, van Deventer JSJ (2011) Time-resolved and spatially-resolved infrared spectroscopic observation of seeded nucleation controlling geopolymer gel formation. J Colloid Interface Sci 357:384-392

[33] Dai Z, Tran TT, Skibsted J (2014) Aluminum incorporation in the C-S-H phase of white portland cement-metakaolin blends studied by 27Al and 29Si MAS NMR spectroscopy. J Am Ceram Soc 97:2662-2671

[34] Girão AV, Richardson IG, Taylor R, Brydson RMD (2010) Composition, morphology and nanostructure of $\mathrm{C}-\mathrm{S}-\mathrm{H}$ in $70 \%$ white Portland cement $-30 \%$ fly ash blends hydrated at $55{ }^{\circ} \mathrm{C}$. Cem Concr Res 40:1350-1359

[35] Tailby J, MacKenzie KJD (2010) Structure and mechanical properties of aluminosilicate geopolymer composites with Portland cement and its constituent minerals. Cem Concr Res 40:787-794

[36] Buchwald A, Hilbig H, Kaps C (2007) Alkali-activated metakaolin-slag blends-performance and structure in dependence of their composition. J Mater Sci 42:3024-3032. https://doi.org/10.1007/s10853-006-0525-6

[37] Dombrowski K, Buchwald A, Weil M (2007) The influence of calcium content on the structure and thermal performance of fly ash based geopolymers. J Mater Sci 42:3033-3043. https://doi.org/10.1007/s10853-006-0532-7

[38] van Deventer JSJ, San Nicolas R, Ismail I, Bernal SA, Brice DG, Provis JL (2014) Microstructure and durability of alkaliactivated materials as key parameters for standardization. J Sustain Cem Based Mater 4:116-128

[39] Ismail I, Bernal S, Provis J, Hamdan S, Deventer JJ (2013) Drying-induced changes in the structure of alkali-activated pastes. J Mater Sci 48:3566-3577. https://doi.org/10.1007/ s10853-013-7152-9

[40] Delaglio F, Grzesiek S, Vuister G, Zhu G, Pfeifer J, Bax A (1995) NMRPipe: a multidimensional spectral processing system based on UNIX pipes. J Biomol NMR 6:277-293 
[41] Massiot D, Fayon F, Capron M, King I, Le Calvé S, Alonso B, Durand J-O, Bujoli B, Gan Z, Hoatson G (2002) Modelling one- and two-dimensional solid-state NMR spectra. Magn Reson Chem 40:70-76

[42] Provis JL, Duxson P, Lukey GC, van Deventer JSJ (2005) Statistical thermodynamic model for $\mathrm{Si} / \mathrm{Al}$ ordering in amorphous aluminosilicates. Chem Mater 17:2976-2986

[43] Fernández-Jiménez A, Palomo A, Sobrados I, Sanz J (2006) The role played by the reactive alumina content in the alkaline activation of fly ashes. Microporous Mesoporous Mater 91:111-119

[44] Lecomte I, Henrist C, Liégeois M, Maseri F, Rulmont A, Cloots R (2006) (Micro)-structural comparison between geopolymers, alkali-activated slag cement and Portland cement. J Eur Ceram Soc 26:3789-3797

[45] Criado M, Fernández-Jiménez A, Palomo A, Sobrados I, Sanz J (2008) Effect of the $\mathrm{SiO}_{2} / \mathrm{Na}_{2} \mathrm{O}$ ratio on the alkali activation of fly ash. Part II: ${ }^{29} \mathrm{Si}$ MAS-NMR Survey. Microporous Mesoporous Mater 109:525-534

[46] Fechtelkord M, Stief F, Buhl J-C (2001) Sodium cation dynamics in nitrate cancrinite: a low and high temperature ${ }^{23} \mathrm{Na}$ and ${ }^{1} \mathrm{H}$ MAS NMR study and high temperature Rietveld structure refinement. Am Miner 86:165-175

[47] Lloyd RR, Provis JL, Deventer JSJ (2009) Microscopy and microanalysis of inorganic polymer cements. 2: the gel binder. J Mater Sci 44:620-631. https://doi.org/10.1007/ s10853-008-3078-Z

[48] Duxson P, Lukey GC, van Deventer JSJ (2006) Evolution of gel structure during thermal processing of Na-geopolymer gels. Langmuir 22:8750-8757

[49] Bakharev T (2006) Thermal behaviour of geopolymers prepared using class F fly ash and elevated temperature curing. Cem Concr Res 36:1134-1147

[50] Provis JL, Yong CZ, Duxson P, van Deventer JSJ (2009) Correlating mechanical and thermal properties of sodium silicate-fly ash geopolymers. Colloids Surf A 336:57-63

[51] Felsche J, Luger S (1987) Phases and thermal decomposition characteristics of hydro-sodalites $\mathrm{Na}_{6+\mathrm{x}},\left[\mathrm{AlSiO}_{4}\right]_{6},(-$ $\mathrm{OH})_{\mathrm{x}} \cdot \mathrm{nH}_{2} \mathrm{O}$. Thermochim Acta 118:35-55

[52] Mitsuda T, Taylor HFW (1978) Normal and anomalous tobermorites. Mineral Mag 42:229-235

[53] Kalousek GL (1952) Application of differential thermal analysis in a study of the system lime-silica-water. In: Third international symposium on the chemistry of cement, cement and concrete association, London

[54] Myers RJ, L'Hôpital ÉM, Provis JL, Lothenbach B (2015) Effect of temperature and aluminium on calcium (alumino)silicate hydrate chemistry under equilibrium conditions. Cem Concr Res 68:83-93
[55] Myers RJ, Bernal SA, Gehman JD, van Deventer JSJ, Provis JL (2015) The role of Al in cross-linking of alkali-activated slag cements. J Am Ceram Soc 98:996-1004

[56] Lloyd RR, Provis JL, van Deventer JSJ (2009) Microscopy and microanalysis of inorganic polymer cements. 1: remnant fly ash particles. J Mater Sci 44:608-619. https://doi.org/10. 1007/s10853-008-3077-0

[57] Fernández-Jiménez A, Palomo A (2005) Composition and microstructure of alkali activated fly ash binder: effect of the activator. Cem Concr Res 35:1984-1992

[58] Winnefeld F, Leemann A, Lucuk M, Svoboda P, Neuroth M (2010) Assessment of phase formation in alkali activated low and high calcium fly ashes in building materials. Constr Build Mater 24:1086-1093

[59] Bernal SA, San Nicolas R, Myers RJ, Mejía de Gutiérrez R, Puertas F, van Deventer JSJ, Provis JL (2014) MgO content of slag controls phase evolution and structural changes induced by accelerated carbonation in alkali-activated binders. Cem Concr Res 57:33-43

[60] Wang S-D, Scrivener KL (2003) ${ }^{29} \mathrm{Si}$ and ${ }^{27} \mathrm{Al}$ NMR study of alkali-activated slag. Cem Concr Res 33:769-774

[61] Palomo A, Alonso S, Fernández-Jiménez A, Sobrados I, Sanz J (2004) Alkaline activation of fly ashes: NMR study of the reaction products. J Am Ceram Soc 87:1141-1145

[62] Merwin LH, Sebald A, Rager H, Schneider H (1991) ${ }^{29} \mathrm{Si}$ and ${ }^{27}$ Al MAS NMR spectroscopy of mullite. Phys Chem Miner 18:47-52

[63] Kowalczyk G, Roberts JE (1994) Solid State ${ }^{29}$ Si NMR determination of crystalline silica in natural iron oxide pigments. Anal Chim Acta 286:25-35

[64] Myers S, Cygan R, Assink R, Boslough M (1998) ${ }^{29}$ Si MAS NMR relaxation study of shocked Coconino Sandstone from Meteor Crater, Arizona. Phys Chem Miner 25:313-317

[65] Le Saoût G, Ben Haha M, Winnefeld F, Lothenbach B, Jantzen C (2011) Hydration degree of alkali-activated slags: a ${ }^{29}$ Si NMR study. J Am Ceram Soc 94:4541-4547

[66] Bonk F, Schneider J, Cincotto MA, Panepucci HC (2003) Characterization by multinuclear high-resolution NMR of hydration products in activated blast-furnace slag pastes. J Am Ceram Soc 86:1712-1719

[67] Lippmaa ASE, Mägi M (1986) High-resolution ${ }^{27}$ Al NMR of aluminosilicates. J Am Chem Soc 108:1730-1735

[68] Moesgaard M, Keding R, Skibsted J, Yue Y (2010) Evidence of intermediate-range order heterogeneity in calcium aluminosilicate glasses. Chem Mater 22:4471-4483

[69] Murdoch JB, Stebbins JF, Carmichael ISE (1985) Highresolution ${ }^{29} \mathrm{Si}$ NMR study of silicate and aluminosilicate glasses: the effect of network-modifying cations. Am Miner $70: 370-382$ 
[70] Walkley B, San Nicolas R, Sani M-A, Gehman JD, van Deventer JSJ, Provis JL (2016) Synthesis of stoichiometrically controlled reactive aluminosilicate and calcium-aluminosilicate powders. Powder Technol 297:17-33

[71] Engelhardt G, Michel D (1987) High-resolution solid state NMR of silicates and zeolites. Wiley, Chichester

[72] Duxson P, Provis JL, Lukey GC, Separovic F, van Deventer JSJ (2005) ${ }^{29} \mathrm{Si}$ NMR study of structural ordering in aluminosilicate geopolymer gels. Langmuir 21:3028-3036

[73] Skibsted J, Jakobsen HJ, Hall C (1995) Quantification of calcium silicate phases in Portland cements by ${ }^{29} \mathrm{Si}$ MAS NMR spectroscopy. J Chem Soc Faraday Trans 91:4423-4430

[74] Lippmaa E, Mägi M, Tarmak M, Wieker W, Grimmer AR (1982) A high resolution ${ }^{29} \mathrm{Si}$ NMR study of the hydration of tricalciumsilicate. Cem Concr Res 12:597-602

[75] Stebbins JF, Murdoch JB, Carmichael ISE, Pines A (1986) Defects and short-range order in nepheline group minerals: a silicon-29 nuclear magnetic resonance study. Phys Chem Miner 13:371-381

[76] Lippmaa E, Maegi M, Samoson A, Engelhardt G, Grimmer AR (1980) Structural studies of silicates by solid-state highresolution silicon-29 NMR. J Am Chem Soc 102:4889-4893
[77] Engelhardt G, Felsche J, Sieger P (1992) The hydrosodalite system $\mathrm{Na}_{6+\mathrm{x}}\left[\mathrm{SiAlO}_{4}\right]_{6}(\mathrm{OH})_{\mathrm{x}} \cdot n \mathrm{H}_{2} \mathrm{O}$ : formation, phase composition, and de- and rehydration studied by ${ }^{1} \mathrm{H},{ }^{23} \mathrm{Na}$, and ${ }^{29} \mathrm{Si}$ MAS-NMR spectroscopy in tandem with thermal analysis, x-ray diffraction, and IR spectroscopy. J Am Chem Soc 114:1173-1182

[78] Hansen MR, Jakobsen HJ, Skibsted J (2003) ${ }^{29}$ Si chemical shift anisotropies in calcium silicates from high-field ${ }^{29} \mathrm{Si}$ MAS NMR spectroscopy. Inorg Chem 42:2368-2377

[79] Viallis H, Faucon P, Petit JC, Nonat A (1999) Interaction between salts $(\mathrm{NaCl}, \mathrm{CsCl})$ and calcium silicate hydrates (C - S-H). J Phys Chem B 103:5212-5219

[80] Duxson P, Lukey GC, Separovic F, van Deventer JSJ (2005) Effect of alkali cations on aluminum incorporation in geopolymeric gels. Ind Eng Chem Res 44:832-839

[81] Stebbins JF, Farnan I, Williams EH, Roux J (1989) Magic angle spinning NMR observation of sodium site exchange in nepheline at $500{ }^{\circ} \mathrm{C}$. Phys Chem Miner 16:763-766

[82] Buhl JC, Engelhardt G, Felsche J, Luger S, Foerster H (1988) ${ }^{23} \mathrm{Na}$ MAS-NMR and ${ }^{1} \mathrm{H}$ MAS-NMR studies in the hydro-sodalite system. Ber Bunsenges Phys Chem 92:176-181 